\title{
INTELLECTUAL PROPERTY RIGHTS AND FOREIGN TECHNOLOGY LICENSING IN DEVELOPING COUNTRIES: AN EMPIRICAL INVESTIGATION
}

Elisabetta Gentile

NO. 515

July 2017
ADB ECONOMICS WORKING PAPER SERIES 
ADB Economics Working Paper Series

\section{Intellectual Property Rights and Foreign Technology Licensing in Developing Countries: An Empirical Investigation}

Elisabetta Gentile

No. 515 | July 2017
Elisabetta Gentile (egentile@adb.org) is an economist at the Economic Research and Regional Cooperation Department, Asian Development Bank

I am forever grateful to Dietrich Vollrath for his mentorship. I also thank John Ham, Scott Imberman, Walter Park, Ivan Png, and the two anonymous referees for their helpful suggestions. I also thank the World Bank Enterprise Surveys Team for their support. Finally, I thank the conference participants at the Fall 2011 Research Conference of the Association for Public Policy Analysis and Management, and the 81st Annual Meetings of the Southern Economic Association, as well as seminar attendees at the Asian Development Bank. 
(C) 2017 Asian Development Bank

6 ADB Avenue, Mandaluyong City, 1550 Metro Manila, Philippines

Tel +63 2632 4444; Fax +6326362444

www.adb.org

Some rights reserved. Published in 2017.

ISSN 2313-6537 (Print), 2313-6545 (e-ISSN)

Publication Stock No. WPS178928-2

DOI: http://dx.doi.org/10.22617/WPS178928-2

The views expressed in this publication are those of the authors and do not necessarily reflect the views and policies of the Asian Development Bank (ADB) or its Board of Governors or the governments they represent.

ADB does not guarantee the accuracy of the data included in this publication and accepts no responsibility for any consequence of their use. The mention of specific companies or products of manufacturers does not imply that they are endorsed or recommended by ADB in preference to others of a similar nature that are not mentioned.

By making any designation of or reference to a particular territory or geographic area, or by using the term "country" in this document, $A D B$ does not intend to make any judgments as to the legal or other status of any territory or area.

This work is available under the Creative Commons Attribution 3.0 IGO license (CC BY 3.0 IGO)

https://creativecommons.org/licenses/by/3.0/igo/. By using the content of this publication, you agree to be bound by the terms of this license. For attribution, translations, adaptations, and permissions, please read the provisions and terms of use at https://www.adb.org/terms-use\#openaccess

This CC license does not apply to non-ADB copyright materials in this publication. If the material is attributed to another source, please contact the copyright owner or publisher of that source for permission to reproduce it. $\mathrm{ADB}$ cannot be held liable for any claims that arise as a result of your use of the material.

Please contact pubsmarketing@adb.org if you have questions or comments with respect to content, or if you wish to obtain copyright permission for your intended use that does not fall within these terms, or for permission to use the ADB logo.

Notes:

1. In this publication, “\$” refers to US dollars.

2. Corrigenda to ADB publications may be found at http://www.adb.org/publications/corrigenda 


\section{CONTENTS}

TABLES AND FIGURES

ABSTRACT V v

$\begin{array}{ll}\text { I. INTRODUCTION } & 1\end{array}$

II. ANALYSIS OF EXISTING LITERATURE

III. EMPIRICAL STRATEGY

$\begin{array}{lll}\text { IV. } & \text { DATA }\end{array}$

V. INTELLECTUAL PROPERTY PROTECTION AND TECHNOLOGY LICENSING 12

A. Affiliated versus Unaffiliated Firms $\quad 14$

B. Development Stage 17

C. Firm-Level Endogeneity 19

VI. CONCLUSION $\quad 22$

$\begin{array}{ll}\text { APPENDIX } & 25\end{array}$

$\begin{array}{ll}\text { REFERENCES } & 35\end{array}$ 


\section{TABLES AND FIGURES}

\section{TABLES}

$1 \quad$ Country-Level Variables $\quad 9$

2 Summary Statistics of Firm-Level Variables by Foreign Technology Licensing Status 10

3 Proportion of Foreign Technology Licensees by Sector

$4 \quad$ Linear Probability Model of the Relationship between IP Protection and Foreign

Technology Licensing

$\begin{array}{ll}5 & \text { Summary Statistics of Unaffiliated versus Affiliated Firms } \\ 6 & \text { Linear Probability Model of the Relationship between IP Protection and Foreign }\end{array}$

Technology Licensing for the Subpopulations of Unaffiliated versus Affiliated Firms

$7 \quad$ Linear Probability Model of the Relationship between IP Protection and Foreign Technology Licensing by Income Level

8 Linear Probability Model of the Relationship between IP Protection and Foreign Technology Licensing for the Subpopulations of Unaffiliated Small and Medium Enterprises with Domestic Sales

A.1 Overview of the Dataset

A.2 Index of Patent Rights by Country by Year

A.3 Overview of the Subpopulation of Small and Medium Enterprises with Domestic Ownership and Domestic Sales

\section{FIGURES}

$1 \quad$ Index of Patent Rights by Income Level

2 Restricted cubic spline smooth of proportion of licensees given the level of IPR 


\begin{abstract}
The paper addresses the question of whether expanded and strengthened protection of intellectual property (IP) fosters technology transfer to developing countries. Cross-sectional analysis of a representative sample of firms operating in 42 developing economies indicates that going from no IP protection to maximum IP protection is associated with a $65 \%$ increase in the predicted probability of licensing foreign technology for the subpopulation of affiliated firms, whereas the predicted probability is not significantly different from zero for unaffiliated firms. We also find evidence that the environment in which a firm operates moderates the relationship of IP protection and firm-level technology licensing: while going from no IP protection to maximum IP protection is associated with a $47 \%$ increase in the predicted probability of licensing foreign technology for firms operating in upper-middle-income countries, there is at best no significant correlation for firms operating in lower-middle-income and lowincome countries.
\end{abstract}

Keywords: developing countries, intellectual property rights, technology licensing, TRIPS Agreement

JEL codes: $L 24,014,019,034$ 


\section{INTRODUCTION}

In 2010, $70 \%$ of patent applications filed worldwide originated in high-income economies, whereas lower-middle-income and low-income economies combined contributed less than 4\%. ${ }^{1}$ Thus, in developing countries, productivity growth relies heavily on the successful adoption and adaptation of foreign technology.

The Agreement on Trade-Related Aspects of Intellectual Property Rights (TRIPS) was conceived with the objective to "contribute to the [...] transfer and dissemination of technology, to the mutual advantage of producers and users of technological knowledge and in a manner conducive to social and economic welfare" (GATT 1994). ${ }^{2}$ Twenty years later, it is still the subject of vigorous debate whether intellectual property standards facilitate or impede technology transfer. The "traditional" view is that strong patent rights promote technology transfer to firms in developing countries, by giving patent owners more control over who gains access, and under what conditions, thus making them more willing to enter into licensing agreements. On the other hand, stronger intellectual property (IP) protection consolidates the monopoly power of patent holders, which makes it costlier for firms in developing countries to license foreign technology, ultimately reducing follow-on innovation in the developing world.

The abundant theoretical literature on this topic consists of product cycle models in which only two regions exist: "North" and "South." North is industrially developed and has the ability to create new technologies, whereas South is less developed and cannot innovate: it can only imitate Northern technologies. Since Southern firms have a cost advantage in manufacturing, they can capture the market by imitating Northern technologies. However, as the cost of imitation increases, it erodes the Southern production cost advantage to the benefit of Northern firms.

Helpman (1993) presents three versions of the model described above: (1) innovation is exogenous, and cross-border investment is not allowed; (2) innovation is endogenous, and cross-border investment is not allowed; (3) innovation is endogenous, and cross-border investment is allowed. In all three versions, tighter IP protection unambiguously hurts the South, whereas it is possible that the benefits outweigh the costs for the North.

The intuition behind the findings from versions (1) and (2) is straightforward: if Southern firms can't imitate Northern technology, they cannot compete with Northern firms, which means that production remains in (or relocates to) the North. That is a source of inefficiency, because the cost of production would be lower in the South, and both regions are worse off because of it. Such (re)allocation of production also deteriorates the terms of trade in the South, whereas it improves them in the North; therefore, the North can benefit from tighter IP protection if the gains from improved terms of trade outweigh the efficiency loss.

When foreign direct investment (FDI) is allowed (version 3), stronger IP rights in the South bring about more FDI from the North, but not enough to outweigh the negative welfare effects of higher consumer prices. For the North, on the other hand, the negative welfare effect of higher consumer prices could be outweighed by the positive income effect from foreign investment.

\footnotetext{
Author's calculations based on data from http://ipstats.wipo.int/ipstatv2/ accessed on March 3, 2017.
}

2 For a historical background on IP protection, refer to the Appendix. 
Helpman (1993) provides a useful framework to study the effect of tighter IP protection on less developed economies, although his findings are not necessarily robust to model specification. For example, Lai (1998) extends the model in Helpman (1993) with endogenous innovation and FDI, and his findings are similar when imitation is the only channel of production transfer. However, when imitation and FDI coexist, the South benefits from tighter IP protection, as Northern FDI more than offsets the increased cost of imitation. Conversely, Glass and Saggi (2002) present a product cycle model in which innovation, imitation, and FDI are endogenous, but they find that the increased difficulty of imitation reduces both FDI and innovation in the South. Finally, both Yang and Maskus (2001b), and Dinopoulos and Segerstrom (2010) find positive effects of stronger IP rights on North-South technology transfer.

This brief review of the theoretical literature leads to two important conclusions. First, there are two effects of stronger IP rights on developing economies at play, pulling in different directions: on the one hand, the cost of imitation; on the other hand, the inflow of FDI. Second, theoretical predictions of the sign and magnitude of the net effect are diverging because they are sensitive to the assumptions underlying the model. Therefore, empirical work is needed to answer this question.

In this paper, we carry out an empirical investigation to assess whether strengthening IP protection in developing countries is associated with an increase in technology licensing from foreign corporations. We use a sample that is representative of the whole population of nonagricultural private firms in 42 developing economies to estimate the relationship between IP protection and arms-length licensing of foreign technology. ${ }^{3}$ Therefore, while prior efforts have focused on outward technology licensing by firms in Organisation for Economic Co-operation and Development (OECD) countriesnamely, the United States (US), Japan, and the European Union-to their affiliates in the rest of the world, we focus on inward technology licensing. Furthermore, we can distinguish between domestic firms and subsidiaries of foreign firms.

We use the Index of Patent Rights in Park (2008), based on the legal IP framework, to measure the strength of IP protection. Although structural estimation is not an option within the context of this study, our reduced-form approach allows us to control for firm-level determinants of technology licensing.

We find that the relationship between IP protection and firm-level licensing of foreign technology is contingent on two factors: first, a firm's ownership structure, in particular, whether it is affiliated to a foreign company, or wholly domestically owned (i.e., unaffiliated); and second, the income level of the country that a firm operates in, which correlates with a host of development outcomes, such as institutional quality, human capital, and infrastructural development. We find that going from no IP protection to maximum IP protection is associated with a $65 \%$ increase in the predicted probability of licensing foreign technology for the subpopulation of affiliated firms, which is statistically significant at $2 \%$ level, whereas the predicted probability is not significantly different from zero for unaffiliated firms. Furthermore, while IP reform is associated with a significant increase in licensing activity for firms operating in upper-middle-income countries, there is at best no significant correlation between the degree of IP protection and technology licensing for firms operating in lower-middle-income and lowincome countries.

3 Following the World Bank classification, we refer to low-income and middle-income economies as "developing economies." 
When working with intellectual property standards, one is inevitably confronted with the issue of endogeneity: do agents within an economy passively adapt to the policy, or do they actively contribute to its determination? In support of the former point, it has been argued that the TRIPS Agreement is forcing IP-importing developing countries to adopt minimum standards of IP protection against the interest of domestic firms (Reichman and Dreyfuss 2007, Yu 2007), suggesting exogeneity. A range of rights, safeguards, and options - the so-called "flexibilities"-were provided under TRIPS to address the needs of developing economies, but many developing countries have not taken advantage of those flexibilities, due to both lack of legal and technical expertise, and pressure from developed countriesthe US in particular - to implement tighter intellectual property standards (Musungu and Oh 2005, Braithwaite and Drahos 2000). ${ }_{4}^{4}$ However, even granted that the legal framework for IP protection is exogenously determined, a country can still decide the extent of the resources allocated to the enforcement of those rights.

We perform a number of robustness checks. First, in order to address bias coming from firmlevel endogeneity, we consider which firms are more likely to exert influence on their governments, based on size, ownership, and sales composition. An analysis of the subpopulation that excludes these firms confirms the main findings. Another source of bias is omitted variables. We include a number of country-level covariates, and we use firm-level data, which allows us to control explicitly for firm characteristics, thus eliminating the bias inherent in cross-country work due to firm composition. In addition, we use sector, year, and country fixed effects to control for unobserved factors, provided that they are time invariant. However, there are other factors that could drive correlations between countrylevel covariates, and therefore the empirical analysis in this study provides only suggestive evidence on causality.

The rest of this paper is structured as follows: Section II provides an overview of the existing empirical literature, section III presents our empirical specification, section IV describes the data, and section $\mathrm{V}$ discusses the results. Finally, section $\mathrm{VI}$ concludes with a discussion of the implications of our results, as well as potential avenues for future research.

\section{ANALYSIS OF EXISTING LITERATURE}

The idea of rewarding innovators for the positive externality that they create lies at the heart of IP protection, and there is mounting evidence that patent laws determine not only the level (see, for example, Moser and Voena (2012), or Kanwar and Evenson (2003), among many others), but also the direction of technical change (Moser 2005). However, Boldrin and Levine (2002) warn that, when implemented as the right to not only own and sell ideas, but also to regulate their use, IP creates a socially inefficient monopoly. Advocates of strong IP protection maintain that its benefits-namely the stimulation of research and development (R\&D), innovation, and ultimately productivity growthoutweigh the costs, but this is not settled in the empirical literature. For example, Kanwar (2012) finds no relation between R\&D investment and IP protection in his study of 40 developed and developing countries.

The relationship between IP protection and R\&D becomes even more relevant in the case of cumulative technological change, where existing IP is an input into follow-on innovation, and therefore access to current IP has an impact on future developments in the same field. In her case study on the sequencing of the human genome, Williams (2013) finds that private IP led to reductions in subsequent

4 For a compelling discussion of the variation in TRIPS implementation, see Deere (2010, Chapter 3). 
scientific research and product development on the order of 20\%-30\%. Sampat and Williams (2015) use administrative data on patent applications to the US Patent Office for human genes, and find that gene patents have had no effect on follow-on innovation. Galasso and Schankerman (2015) study the causal effect of removing patent rights by court invalidation on subsequent research related to the focal patent. They find that patent rights block downstream innovation in computers, electronics, and medical instruments, but not in drugs, chemicals, or mechanical technologies. Interestingly, the effect is entirely driven by invalidation of patents owned by large patentees that triggers more follow-on innovation by small firms.

Since follow-on innovation is the main driver of technological growth in the developing world, these results suggest that IP protection could be detrimental to the interests of developing economies. However, empirical evidence is divergent even in this case. For example, Chaudhuri, Goldberg, and Jia (2006) studied the market for a broad-spectrum antibiotic in India, and estimated substantial welfare losses as a consequence of the extension of patent protection to the pharmaceutical sector for TRIPS compliance; the overwhelming portion of this welfare loss accrued to consumers. On the other hand, Branstetter et al. (2011) studied the effect of substantial IP reform on industrial development in 16 developing countries between 1982 and 1999, and found that the expansion of multinational activity more than offset any decline in imitative activity.

Previous efforts to estimate the effect of increased IP protection on foreign technology licensing in the developing world differ from ours in the data and methodology used. A branch of the IP literature relies on the flow of payments for licensing contracts from one country to another as a proxy for technology transfer. Yang and Maskus (2001a) use aggregate data to look at the effects of patent strength on the flow of unaffiliated royalties and licensing fees by US firms in both absolute and relative terms. They find a negative relationship between IP protection and licensing activity below a certain threshold, and a positive relationship above the same threshold.

The seminal paper by Branstetter, Fisman, and Foley (2006) uses affiliate-level data on US multinational firms to test whether IP rights reform increases the transfer of technology to multinational affiliates operating in reforming countries; Wakasugi and Ito (2007) use a survey of Japanese multinational enterprises (MNEs) to estimate the impact of the degree of IP rights enforcement on the flow of affiliated royalties to the Japanese parent company. Both studies find that these receipts rise with stronger IP rights in the recipient country.

Finally, Zuniga and Guellec (2009) run a multivariate analysis on the determinants of licensing to nonaffiliated parties, using a business survey of patent applicants in the European Union and Japan. They find that firm characteristics such as size, age, sector of activity, and country of origin are significant predictors of a firm being engaged in licensing activity.

In sum, the existing literature has focused on outward licensing from firms in OECD countries to their affiliates in the rest of the world, although unaffiliated technology transfer is an activity of rising importance, as shown by the fact that US receipts of unaffiliated royalties and license fees increased from 31\% of the total in 2000 to 38\% in 2010 (US Department of Commerce 2013). In addition, the existing literature has relied on the inflow of royalty payments to measure the volume of licensing, but an increase in royalty payments does not necessarily imply an increase in the volume of licensing: it could be due to higher licensor rents per contract, rather than a larger number of contracts.

Therefore, by using a stratified sample that is representative of the entire formal, nonagricultural private economy in the developing world, we can achieve two objectives: first, shed some light on the 
licensees, rather than the licensors; second, determine whether the licensing trends that follow IP reform vary based on country and firm characteristics.

\section{EMPIRICAL STRATEGY}

The typical country-level regression analysis has a proxy for cross-country technology transfer, such as the flow of royalty payments from the licensees to the licensor, on the left-hand side, and a measure of IP protection, along with a host of country-level controls, on the right-hand side. Such specification is plagued by omitted variable bias because it does not take into account sector and firm differences between countries, both potential determinants of technology licensing.

The use of firm-level data allows us to control for an array of firm characteristics that might be correlated with the decision to license foreign technology. Therefore, our preferred specification is:

$$
Y_{f s c t}=\alpha+\beta \cdot \text { IPindex }_{c t}+X_{c t} \Gamma+X_{f t} \Omega+\delta_{s}+\varepsilon_{t}+v_{f s c t}
$$

where the response variable of interest, $Y_{\text {fsct, }}$ is a binary variable, which takes the value of 1 if firm $f$ in sector $s$ in country $c$ at time $t$ uses technology licensed from a foreign firm, and zero otherwise:

$$
Y_{f s c t}= \begin{cases}1 & \text { if the firm uses technology licensed from a foreign firm; } \\ 0 & \text { otherwise. }\end{cases}
$$

IPindex $x_{c t}$ is a measure of IP protection in country $c$ at time $t ; X_{f t}$ is a set of observable firm characteristics; $X_{c t}$ is a set of observable country characteristics; $\delta_{s}$ is sector fixed effects; $t$ is year fixed effects; and $v_{f s c t}$ is the error term. ${ }^{5}$

The firm-level data at the basis of this study are stratified by sector of activity, firm size, and geographical location (as discussed in detail in section IV), which requires the use of probability weights for statistical inference on the entire population. The standard errors are clustered by country to take into account intracountry correlation.

Within the context of this study, the empiricist's tools that can be used are limited by two considerations: first, the fact that there is little variation in IP protection within a country over time, as shown in Appendix Table A.2, means that estimates for our independent variable of interest become very noisy with the inclusion of country fixed effects, and in most cases, they are no longer significant (although their magnitude remains remarkably consistent). However, since the inclusion of country fixed effects in the model above addresses the concern that the coefficient for IP protection is capturing unobserved country characteristics, we will present a specification with country fixed effects for each model discussed in section $\mathrm{V}$.

A second consideration concerns the conspicuously unbalanced nature of the panel, added to the fact that eight countries in the sample only have repeated cross sections, and that for the remaining

5 We obtain analogous results if we address the binary nature of the dependent variable by setting $P\left(Y_{f s c t}=1\right)=\pi f_{s c t}$ and $P\left(Y_{f s c t}=0\right)=1-\pi_{f s c t}$, and deriving the following logit model:

$\log \frac{\pi_{f s c t}}{1-\pi_{f s c t}}=\alpha+\beta \cdot I$ Pindex $x_{c t}+X_{c t} \Gamma+X_{f t} \Omega+\delta_{s}+\varepsilon_{t}$ 
34 there is simply not enough within-group and time variation (i.e., firm characteristics such as licensing status, size, sector, and ownership structure tend to remain fairly unchanged over time). The implication is that a longitudinal study is not a viable option.

Therefore, our preferred specification remains the one outlined in equation 1, which includes a number of control variables with variation at the country-year level. This linear probability model alleviates, but does not eliminate the possibility of omitted variable bias.

\section{DATA}

The World Bank Enterprise Surveys (ES) are a centralized database of comparable business climate surveys from around the world. Since 2002, the World Bank has collected this data from face-to-face interviews with top managers and business owners in over 130,000 companies in 135 economies. The sample universe is the entire nonagricultural private economy; therefore, fully government-owned firms are excluded. Surveys are stratified by size, sector, and location, where the primary sampling unit is the "establishment." Establishments within each stratum are randomly selected to participate in the survey, and the design weights are adjusted to take into account the nonresponse rate. A likely consequence of such stratification is that large enterprises are oversampled in the ESs compared to their share in the number of enterprises, but not in terms of their contribution to gross domestic product (GDP) (Aterido and Hallward-Driemeier 2010).

For this study, we selected 33,372 interviews to construct a dataset of firms operating in 42 developing economies spread over four regions, i.e., Europe and Central Asia, Latin America and the Caribbean, Middle East and North Africa, and Sub-Saharan Africa. ${ }^{6}$ As mentioned in section III, we have panels for 34 countries in our sample (although the fraction of firms with repeated observations over time is very small), and cross sections for the remaining eight.

The only selection criterion was that all relevant survey variables be available (and comparable) for at least two cross sections per country. Selection was necessary because although from 2006 onwards, ES questionnaires are administered using a common methodology and a common core survey to enable cross-country analysis and minimize measurement error, among the earlier surveys there is still some variation of the core questions and methodology (Aterido and Hallward-Driemeier 2010; Dethier, Hirn, and Straub 2011).

The outcome of interest for this paper is based on the following survey question:

"Does this establishment at present use technology licensed from a foreign-owned company, excluding office software?"

Respondents select one out of three possible answers: “yes”, “no”, or “I don't know.” Since the "I don't know" responses were less than $1 \%$ of the final sample, we dropped them from our analysis.

Thus, we have information on how many firms are licensing foreign technology, i.e., the extensive margin. Unfortunately, the surveys do not contain questions about the intensive margin, i.e., the actual

6 It was not possible to include in the dataset countries from the Asian regions, i.e., Central Asia, South Asia, and East Asia and the Pacific, because some early surveys were not comparable to the standard format, whereas other surveys had missing variables, or the Index of Patent Rights (IPR) was not available. 
number of licensing contracts, and the related royalty payments; neither it does about the type of technology being licensed.

Table A.1 in the Appendix presents an overview of the dataset: for each country, it specifies the number of observations per year, as well as the weighted proportion of firms that are foreign technology licensees.

We use the Index of Patent Rights (IPR) in Park (2008) to measure country-level IP protection. The IPR is the unweighted sum of five separate scores for: coverage (inventions that are patentable), membership in international treaties, duration of protection, enforcement mechanisms, and restrictions (e.g., compulsory licensing). It ranges between 0 and 5, and is updated every 5 years, which is coherent with the fact that it takes time to enact and implement new legislation.

Appendix Table A. 2 presents the IPR by country by year, for the time period covered by the firmlevel data. Since the index is updated every 5 years, the IPR is the same from 2001 to 2005, and then from 2006 to 2010. The table shows that for 16 out of 42 countries there is no change in the raw IPR during the time period under consideration, presumably because these 16 countries have relatively higher IPR scores to begin with.

Figure 1 represents the mean IPR, scaled to [0,1] for ease of interpretation, within its standard deviation bands, and it has three panels because the 42 countries in the sample are divided into three income groupings: upper-middle-income countries, lower-middle-income countries, and low-income countries. These groupings follow the World Bank classification, which is based on gross national income (GNI) per capita, in US dollars, converted from local currency using the World Bank Atlas method. ${ }^{7}$

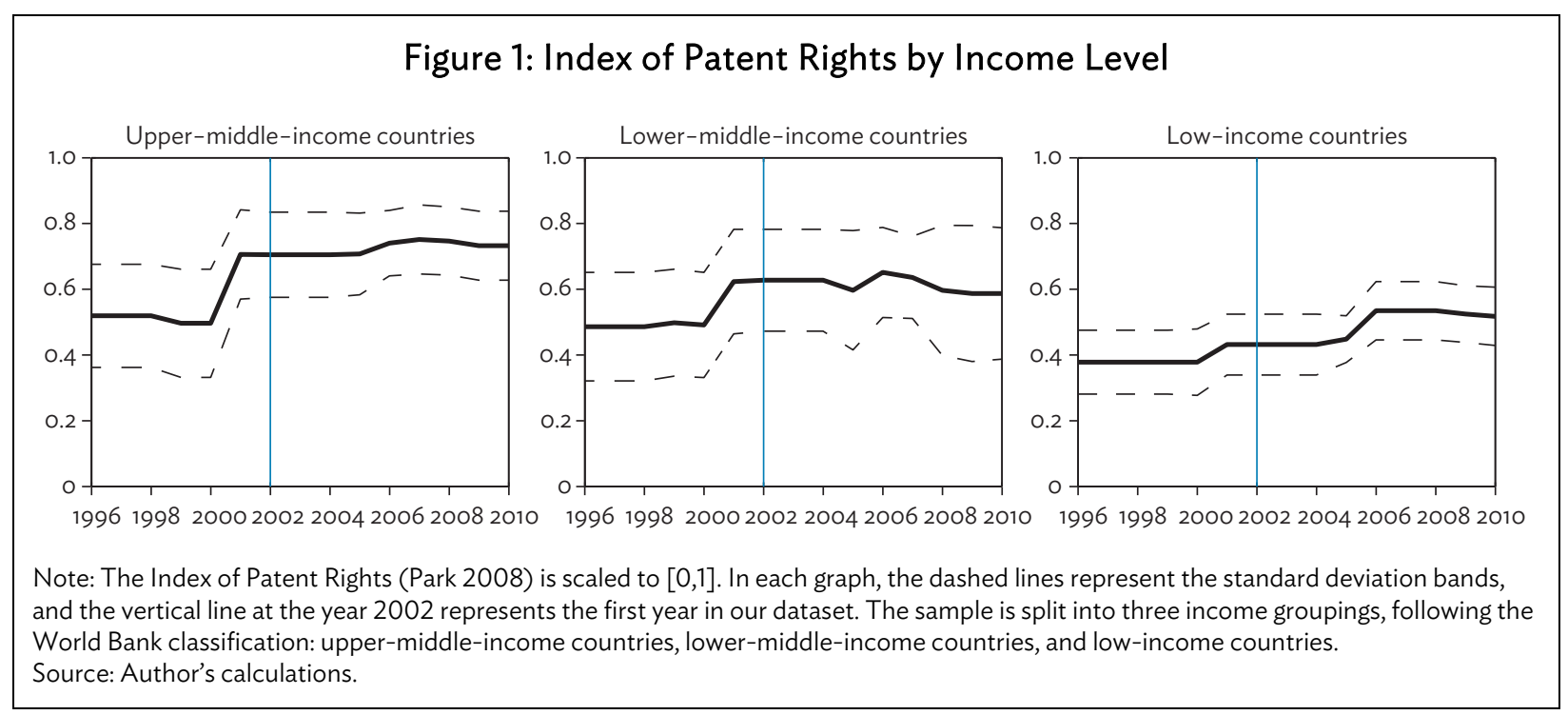

Although GNI per capita has its obvious limitations (e.g., it does not take into account the informal sector, which is sizable in the developing world, and it does not reflect income inequality), "it has proved to be a useful and easily available indicator that is closely correlated with other, nonmonetary

7 The low-, middle-, and high-income group thresholds are updated annually at the beginning of the World Bank's fiscal year (i.e., 1 July), and countries are reassigned based on the estimate of their GNI per capita for the previous calendar year. 
measures of the quality of life, such as life expectancy at birth, mortality rates of children, and enrollment rates in school" (World Bank 2016).

The time series begins in 1996, 1 year after the TRIPS Agreement came into effect. The vertical line at the year 2002 represents the first year in our dataset.

If countries did not move in and out of the three income groupings, the IPR would have a perfect "step ladder" shape, because it is updated every 5 years, and subsequent IP reforms always expand and strengthen protection. The dips and humps that are visible in the IPR curves are due to the fact that 16 out of 42 countries in the dataset experienced a change in classification (i.e., they were moved up to the next income grouping) during the period under consideration.

Overall, Figure 1 shows that in 1996 the mean IPR is highest for upper-middle-income countries, closely followed by lower-middle-income countries; and lowest for the group of low-income countries. By 2010, the gap among the three groupings has widened, because IP protection has been growing faster in upper-middle-income economies than the rest.

While the IPR quantifies the extent of a country's legal framework with respect to intellectual property, it measures enforcement only indirectly, by looking at both statutory and case laws to determine the extent to which IP rights are recognized. The index does not capture such factors as the cost of going to court, how long it takes for a lawsuit to take its course, whether courts have a bias toward domestic firms, all of which can weaken patent rights. Nonetheless, the IPR has been widely used in the literature, and other measures that include enforcement are not without problems. ${ }^{8}$

In examining the relationship between IP protection and technology licensing, a formidable task is to disentangle the effects of IP protection from those of other variables with variation at the country-year level, most notably a country's institutional and socioeconomic characteristics. To address this concern, we add a vector of country-level controls that are widely used and consolidated in the literature.

Following Caselli (2005), we construct a measure of human capital as a piecewise linear function of educational attainment, based on the average years of schooling in the population over 25 years old from Barro and Lee (2010). Human capital may be correlated with both technology licensing and IP protection. On the one hand, adequate human capital is needed for firms to identify productivityenhancing foreign technologies, and then successfully integrate them in their production processes. On the other hand, as human capital increases, new technologies are created domestically, and inventors demand more protection for their IP.

The World Development Indicators provide the remaining country-level covariates. ${ }^{9}$ The index of openness, i.e., the sum of exports and imports of goods and services measured as a share of GDP, is an indication of the extent of the influence of trade on domestic activities. Intense competition incentivizes firms to adopt the latest technologies, and governments to provide domestic innovators with adequate protection from imitation.

8 Another available measure is the raw score on "Intellectual Property Protection" (IPP) from the Executive Opinion Survey (Schwab 2010), which captures enforcement, but covers IP as a whole, not just patents.

9 The World Development Indicators is a well-known collection of the most current and accurate global development data available, compiled by the World Bank. For further information, refer to http://data.worldbank.org/ 
Finally, we control for net FDI as a share of GDP. Foreign investment usually results in the availability of more advanced technology for the domestic market, as well as access to R\&D resources. However, foreign investors are likely to demand adequate IP protection to license out their latest technology: otherwise, they may transfer older production capacity and machines, in order to avoid competition against their own products in the host country.

Conspicuously absent among the country-level controls are the customary indexes of institutional quality and rule of law, because they are highly correlated with the IPR. For example, the two relevant measures from the World Bank's Worldwide Governance Indicators: "Government Effectiveness" and "Rule of Law" have a correlation with the IPR of 0.89 and 0.84 , respectively. In fact, $\mathrm{Hu}$ and Png (2013) and Kanwar (2012) construct a measure of IP protection that is a combination of the IPR with the Fraser index of legal system and property rights (Gwartney, Lawson, and Hall 2012), to get a more complete picture of enforcement. However, as mentioned above, "Enforcement Mechanisms" is one of the five components of the IPR (Park 2008).

\section{Table 1: Country-Level Variables}

(a) Summary statistics by foreign technology licensing status

\begin{tabular}{|c|c|c|c|c|}
\hline & Nonlicensees & Licensees & Total & t-statistic \\
\hline \multirow[t]{2}{*}{ Index of Patent Rights ${ }^{a}$} & 0.657 & 0.654 & 0.657 & 1.145 \\
\hline & $(0.057)$ & $(0.044)$ & $(0.054)$ & \\
\hline \multirow[t]{2}{*}{ Human capital } & 0.680 & 0.673 & 0.679 & 1.251 \\
\hline & $(0.107)$ & $(0.083)$ & $(0.102)$ & \\
\hline \multirow[t]{2}{*}{ Trade (\% of GDP) } & 0.428 & 0.429 & 0.429 & -0.044 \\
\hline & $(0.101)$ & $(0.079)$ & $(0.097)$ & \\
\hline \multirow[t]{2}{*}{ FDI ( $\%$ of GDP) } & 0.018 & 0.018 & 0.018 & 1.326 \\
\hline & $(0.010)$ & $(0.007)$ & $(0.009)$ & \\
\hline \multirow[t]{3}{*}{ Number of observations } & 28,841 & 4,531 & 33,372 & \\
\hline & \multicolumn{4}{|c|}{ (b) Correlation coefficients } \\
\hline & $\begin{array}{c}\text { Index of Patent } \\
\text { Rights }\end{array}$ & $\begin{array}{l}\text { Human } \\
\text { Capital }\end{array}$ & $\begin{array}{c}\text { Trade } \\
\text { (\% of GDP) }\end{array}$ & $\begin{array}{c}\text { FDI } \\
(\% \text { of GDP) }\end{array}$ \\
\hline Index of Patent Rights & 1.000 & & & \\
\hline Human capital & $0.846^{* * *}$ & 1.000 & & \\
\hline Trade ( $\%$ of GDP) & $0.171^{* * *}$ & $0.163^{* * *}$ & 1.000 & \\
\hline FDI ( $\%$ of GDP) & $0.273^{* * *}$ & $0.406^{* * *}$ & $0.428^{* * *}$ & 1.000 \\
\hline
\end{tabular}

$\mathrm{FDI}=$ foreign direct investment, GDP = gross domestic product.

a The IPR is scaled to $[0,1]$ for comparability.

Notes: Standard deviations in parentheses. The t-statistics represent a paired samples statistic with standard errors clustered by country for the null hypothesis that the group means are equal for firms without any foreign technology licensing, and for firms with foreign technology licensing. ${ }^{* * *}$, and ${ }^{* * *}$ denote statistical significance at the $10 \%, 5 \%$, and $1 \%$ levels, respectively.

Source: Author's calculations.

Panel A in Table 1 shows weighted summary statistics for all country-level regressors. In the last column, we report a paired samples statistic with standard errors clustered by country for the null hypothesis that the group means are equal for firms without any foreign technology licensing, and for firms with foreign technology licensing. We fail to reject the null hypothesis for all four variables.

Panel B in Table 1 presents the weighted correlation coefficients for all country-level regressors. The correlation between the IPR and human capital is by far the highest at 0.85 , whereas the rest of the country-level covariates have relatively low correlations. 
Table 2 presents summary statistics for all firm-level regressors: first, a series of basic firm characteristics (e.g., size, legal status, ownership structure, and age), followed by import and export status, and fixed assets financing structure. Once again, in the last column, we report a paired samples statistic with standard errors clustered by country for the null hypothesis that the group means are equal for firms without any foreign technology licensing, and for firms with foreign technology licensing.

Table 2: Summary Statistics of Firm-Level Variables by Foreign Technology Licensing Status

\begin{tabular}{|c|c|c|c|c|}
\hline & Nonlicensees & Licensees & Total & t-statistic \\
\hline \multirow[t]{2}{*}{ Firm size (FTEs/1,000) } & 0.0267 & 0.0730 & 0.0352 & -0.910 \\
\hline & $(0.1460)$ & $(0.4117)$ & $(0.2422)$ & \\
\hline \multirow[t]{2}{*}{ Indicator for publicly listed company } & 0.0066 & 0.0189 & 0.0088 & $-10.662^{* * *}$ \\
\hline & $(0.0832)$ & $(0.1174)$ & $(0.0936)$ & \\
\hline \multirow[t]{2}{*}{ Indicator for privately held, LLC } & 0.1848 & 0.1869 & 0.1852 & -0.235 \\
\hline & $(0.3992)$ & $(0.3356)$ & $(0.3884)$ & \\
\hline \multirow[t]{2}{*}{ Indicator for sole proprietorship } & 0.7532 & 0.7510 & 0.7528 & 0.170 \\
\hline & $(0.4435)$ & $(0.3723)$ & $(0.4314)$ & \\
\hline \multirow[t]{2}{*}{ Indicator for partnership / limited partnership } & 0.0527 & 0.0413 & 0.0506 & $1.858^{*}$ \\
\hline & $(0.2298)$ & $(0.1713)$ & $(0.2192)$ & \\
\hline \multirow[t]{2}{*}{ Indicator for other legal status } & 0.0027 & 0.0019 & 0.0026 & 0.760 \\
\hline & $(0.0536)$ & $(0.0371)$ & $(0.0506)$ & \\
\hline \multirow[t]{2}{*}{ Fraction with private domestic ownership } & 0.9890 & 0.9389 & 0.9798 & 1.426 \\
\hline & $(0.0993)$ & $(0.1968)$ & $(0.1325)$ & \\
\hline \multirow[t]{2}{*}{ Fraction with private foreign ownership } & 0.0091 & 0.0458 & 0.0158 & -1.095 \\
\hline & $(0.0917)$ & $(0.1699)$ & $(0.1176)$ & \\
\hline \multirow[t]{2}{*}{ Fraction with government/state ownership } & 0.0006 & 0.0004 & 0.0006 & 1.102 \\
\hline & $(0.0173)$ & $(0.0121)$ & $(0.0164)$ & \\
\hline \multirow{2}{*}{ Fraction with other ownership } & 0.0013 & 0.0148 & 0.0038 & $-9.154^{* * *}$ \\
\hline & $(0.0315)$ & $(0.1014)$ & $(0.0577)$ & \\
\hline \multirow[t]{2}{*}{ Firm age (years/100) } & 0.1746 & 0.1984 & 0.1790 & $-13.713^{* * *}$ \\
\hline & $(0.1182)$ & $(0.1060)$ & $(0.1168)$ & \\
\hline \multirow[t]{2}{*}{ Fraction of domestic sales } & 0.9817 & 0.9703 & 0.9796 & 1.614 \\
\hline & $(0.1030)$ & $(0.1042)$ & $(0.1043)$ & \\
\hline \multirow[t]{2}{*}{ Fraction of indirect exports } & 0.0058 & 0.0097 & 0.0065 & $-3.774^{* * *}$ \\
\hline & $(0.0543)$ & $(0.0549)$ & $(0.0550)$ & \\
\hline \multirow[t]{2}{*}{ Fraction of direct exports } & 0.0125 & 0.0200 & 0.0139 & -1.220 \\
\hline & $(0.0850)$ & $(0.0863)$ & $(0.0862)$ & \\
\hline \multirow[t]{2}{*}{ Indicator for direct importer of inputs ${ }^{a}$} & 0.0536 & 0.1011 & 0.0623 & -1.263 \\
\hline & $(0.2316)$ & $(0.2595)$ & $(0.2416)$ & \\
\hline \multirow{2}{*}{$\begin{array}{l}\text { Fraction of fixed assets financed with internal } \\
\text { funds/retained earnings }\end{array}$} & 0.4024 & 0.3859 & 0.3993 & 0.915 \\
\hline & $(0.4861)$ & $(0.4008)$ & $(0.4713)$ & \\
\hline \multirow{2}{*}{$\begin{array}{l}\text { Fraction of fixed assets financed with } \\
\text { bank loans }\end{array}$} & 0.0437 & 0.0503 & 0.0449 & -3.067 \\
\hline & $(0.1841)$ & $(0.1636)$ & $(0.1810)$ & \\
\hline \multirow{2}{*}{$\begin{array}{l}\text { Fraction of fixed assets financed with } \\
\text { trade credit }\end{array}$} & 0.0240 & 0.0342 & 0.0259 & -3.574 \\
\hline & $(0.1300)$ & $(0.1298)$ & $(0.1312)$ & \\
\hline \multirow{2}{*}{$\begin{array}{l}\text { Fraction of fixed assets financed with owners' } \\
\text { contribution/new equity shares }\end{array}$} & 0.0028 & 0.0039 & 0.0030 & -0.775 \\
\hline & $(0.0453)$ & $(0.0411)$ & $(0.0448)$ & \\
\hline \multirow{2}{*}{$\begin{array}{l}\text { Fraction of fixed assets financed with } \\
\text { other means }\end{array}$} & 0.0166 & 0.0169 & 0.0166 & -0.194 \\
\hline & $(0.0941)$ & $(0.0932)$ & $(0.0948)$ & \\
\hline Number of observations & 28,841 & 4,531 & 33,372 & \\
\hline
\end{tabular}

FTEs = full-time equivalents, LLC = limited liability company.

a The exact breakdown of directly and indirectly imported production inputs is not available.

Source: Author's calculations. 
Table 2 shows significant correlations between firm characteristics and technology licensing status: licensees tend to be publicly listed companies, and they tend to have different ownership structures; they are more likely to be indirect exporters, and to have more years of operation. The summary statistics also suggest that licensees have access to bank loans and trade credit to finance their fixed asset purchases.

Interestingly, the differences in mean firm size and fraction of foreign ownership between nonlicensees and licensees are both statistically insignificant. Although licensees employ more people (73 versus 26 full-time equivalents) and have a higher fraction of foreign ownership (roughly $5 \%$ versus $1 \%)$ on average, there is remarkable dispersion in the distribution.

On average, $18 \%$ of the firms in the sample are foreign technology licensees. In Table 3, we present the weighted proportions of licensees by sector of operation: out of 18 categories, 12 are manufacturing, representing $94 \%$ of the sample. The remaining six are nonmanufacturing firms. ${ }^{10}$

Table 3: Proportion of Foreign Technology Licensees by Sector

\begin{tabular}{lcrr}
\hline & Nonlicensees & Licensees & Observations \\
\hline & \multicolumn{2}{c}{} \\
\cline { 2 - 4 } Textiles & 0.75 & (a) Manufacturing \\
Leather & 0.79 & 0.25 & 2,536 \\
Garments & 0.88 & 0.21 & 839 \\
Food and beverages & 0.82 & 0.12 & 5,047 \\
Metals and machinery & 0.83 & 0.18 & 6,672 \\
Electronics & 0.93 & 0.17 & 4,708 \\
Chemicals and pharmaceuticals & 0.80 & 0.07 & 487 \\
Wood, furniture and crafts & 0.75 & 0.20 & 3,067 \\
Nonmetallic and plastic materials & 0.86 & 0.25 & 2,798 \\
Paper and printing & 0.78 & 0.14 & 2,911 \\
Auto, auto components and other transport & & 0.23 & 969 \\
$\quad$ equipment & 0.81 & 0.19 & 418 \\
Other manufacturing & 0.64 & 0.36 & 973 \\
\cline { 2 - 4 } Subtotal & & & 31,425
\end{tabular}

Agroindustry

Mining and quarrying

Construction

Wholesale and retail trade

Real estate, renting and business activities

Other services

Subtotal

\begin{tabular}{ccc}
\multicolumn{3}{c}{ (b) Non-manufacturing } \\
\hline 0.84 & 0.16 & 294 \\
0.28 & 0.72 & 40 \\
0.75 & 0.25 & 371 \\
0.89 & 0.11 & 759 \\
0.72 & 0.29 & 162 \\
0.90 & 0.11 & 321 \\
\hline & & \\
0.85 & 0.15 & 1,947 \\
0.82 & 0.18 & 33,372 \\
\hline
\end{tabular}

Total

a Sectors are classified as "Manufacturing" or "Non-manufacturing" based on the International Standard Industrial Classification of All Economic Activities, Rev.4.

Source: Author's calculations.

10 Sectors are classified as "Manufacturing" or "Non-manufacturing" based on the International Standard Industrial Classification of All Economic Activities, Rev.4. 
Overall, Table 3 shows that there is a wide variation in the extensive margin of licensing across sectors of operation. Although manufacturing as a whole has a higher proportion of licensees than nonmanufacturing (18\% and 15\%, respectively), it is "Mining and quarrying," a nonmanufacturing sector, that has the highest proportion of licensees, at $72 \%{ }^{11}$

Thus, the summary statistics suggest that a host of factors at the firm, sector, and country level, besides IP protection, influence licensing activity. That lends support to the empirical strategy outlined in section III.

\section{INTELLECTUAL PROPERTY PROTECTION AND TECHNOLOGY LICENSING}

Table 4 displays the results of the weighted linear probability model over the pooled sample. Column (1) is the baseline specification with only country-level covariates, whereas columns (2) through (4) are the preferred specification in equation 1, with an increasing number of firm characteristics, as well as year, sector, and legal status fixed effects. In particular, the firm characteristics included in column (2) correspond to the "basic" group in Table 2 (size, age, ownership structure); those included in column (3) are the basic group, plus import and export status; column (4) contains the basic group, import and export status, and fixed assets financing structure; finally, column (5) includes all firm-level controls, the IPR, and country fixed effects. This is not a preferred specification, for reasons already explained in section III, and it is included solely for completeness of information.

The coefficient for IPR is negative and insignificant in column (1); however, as we add an increasing number of firm characteristics, it becomes positive in columns (2) through (5), where the change in the predicted probability of being a licensee for a one-unit change in the IPR, holding everything else constant, hovers between $15 \%$ and $23 \%$. Since the IPR has been rescaled to [0,1], a oneunit change means going from no IP protection to maximum IP protection. The raw IPR ranges from 0 to 5 , which means that the change in the predicted probability of being a licensee for a one-unit change in the raw IPR is roughly $3 \%$ in columns (2) through (4), and $4 \%$ in column (5).

Among the country-level covariates, human capital is negative and insignificant in column (1), but it becomes significant at the $1 \%$ level in columns (2) to (4). It may indicate that, as the level of human capital rises, an economy is increasingly able to boost productivity by creating its own technology. There are also significant correlations between a firm's characteristics-size, ownership, age, import status, and access to finance - and its technology licensing status, as pointed out by Zuniga and Guellec (2009).

The results in Table 4 seem to imply a positive, albeit insignificant, relationship between IP protection and licensing. However, there is a concrete possibility that one or more subpopulations of firms are driving the results for the pooled sample.

1 Unfortunately, the Enterprise Surveys do not collect any information on copyright, a type of IP that is likely to be more relevant to the services sector. 


\section{Table 4: Linear Probability Model of the Relationship between IP Protection and Foreign Technology Licensing}

\begin{tabular}{|c|c|c|c|c|c|}
\hline & $\begin{array}{c}\text { Baseline } \\
\text { (1) }\end{array}$ & $\begin{array}{c}\text { Col. } 1 \text { Plus Firm } \\
\text { Characteristics } \\
\text { (2) }\end{array}$ & $\begin{array}{l}\text { Col. } 2 \text { Plus } \\
\text { Import and } \\
\text { Export Status } \\
(3)\end{array}$ & $\begin{array}{l}\text { Col. } 3 \text { Plus } \\
\text { Financing of } \\
\text { Fixed Assets } \\
\text { (4) }\end{array}$ & $\begin{array}{l}\text { Country Fixed } \\
\text { Effects and Firm- } \\
\text { Level Controls } \\
\text { (5) }\end{array}$ \\
\hline Index of Patent Rights & $(0.092)$ & $(0.090)$ & $(0.097)$ & $(0.103)$ & $(0.202)$ \\
\hline \multirow[t]{2}{*}{ Human capital } & -0.068 & $-0.245^{* * *}$ & $-0.265^{* * *}$ & $-0.280^{* * *}$ & \\
\hline & $(0.041)$ & $(0.067)$ & $(0.073)$ & $(0.078)$ & \\
\hline \multirow[t]{2}{*}{ Foreign direct investment ( $\%$ of GDP) } & -0.345 & -0.279 & -0.352 & -0.339 & \\
\hline & $(0.284)$ & $(0.306)$ & $(0.306)$ & $(0.318)$ & \\
\hline \multirow[t]{2}{*}{ Firm size (FTEs/1,000) } & & $0.142^{* * *}$ & $0.120^{* * *}$ & $0.115^{* * *}$ & $0.117^{* * *}$ \\
\hline & & $(0.024)$ & $(0.024)$ & $(0.025)$ & $(0.022)$ \\
\hline \multirow[t]{2}{*}{ Firm size (FTEs/1,000) squared } & & $-0.009^{* * *}$ & $-0.007^{* * *}$ & $-0.007^{* * *}$ & $-0.007^{* * *}$ \\
\hline & & $(0.002)$ & $(0.002)$ & $(0.002)$ & $(0.002)$ \\
\hline Fraction with other ownership & & $(0.111)$ & $(0.112)$ & $(0.112)$ & $(0.110)$ \\
\hline \multirow[t]{2}{*}{ Firm age (years/100) } & & $0.444^{* * *}$ & $0.437^{* * *}$ & $0.444^{* * *}$ & $0.459^{* * *}$ \\
\hline & & $(0.082)$ & $(0.091)$ & $(0.098)$ & $(0.090)$ \\
\hline \multirow[t]{2}{*}{ Firm age squared } & & $-0.477^{* * *}$ & $-0.491^{* * *}$ & $-0.496^{* * *}$ & $-0.510^{* * *}$ \\
\hline & & $(0.118)$ & $(0.129)$ & $(0.136)$ & $(0.131)$ \\
\hline \multirow[t]{2}{*}{ Fraction of indirect exports } & & & 0.119 & 0.122 & 0.130 \\
\hline & & & $(0.117)$ & $(0.121)$ & $(0.125)$ \\
\hline \multirow[t]{2}{*}{ Fraction of direct exports } & & & -0.008 & -0.007 & -0.005 \\
\hline & & & $(0.044)$ & $(0.043)$ & $(0.043)$ \\
\hline \multirow[t]{2}{*}{ Dummy variable for direct importer of inputs } & & & $0.079^{* * *}$ & $0.076^{* * *}$ & $0.083^{* * *}$ \\
\hline & & & $(0.008)$ & $(0.009)$ & $(0.008)$ \\
\hline Fraction of fixed assets financed with bank loans & & & & $0.038^{* *}$ & $0.043^{* * *}$ \\
\hline Intercept & $(0.047)$ & $(0.110)$ & $(0.108)$ & $(0.114)$ & $(0.048)$ \\
\hline Number of observations & 33,372 & 33,372 & 33,372 & 33,372 & 33,372 \\
\hline Country fixed effects & $\mathrm{N}$ & $\mathrm{N}$ & $\mathrm{N}$ & $\mathrm{N}$ & Y \\
\hline Sector fixed effects & $\mathrm{N}$ & Y & Y & Y & Y \\
\hline Year fixed effects & $\mathrm{N}$ & Y & Y & Y & Y \\
\hline Legal status fixed effects & $\mathrm{N}$ & Y & $Y$ & Y & $Y$ \\
\hline
\end{tabular}

FTEs = full-time equivalents, GDP = gross domestic product, IP = intellectual property.

Notes: Standard errors of the means clustered by country in parentheses. Columns (2) through (4) include sector and year fixed effects, along with a firm's legal status of publicly listed company, privately held/limited liability company, and partnership/limited partnership, with sole proprietorship being the excluded category. Column (5) includes sector, country, year, and legal status fixed effects. * **, and ${ }^{* * *}$ denote statistical significance at the 10\%, 5\%, and $1 \%$ levels, respectively.

Source: Author's calculations. 


\section{A. Affiliated versus Unaffiliated Firms}

As mentioned in section II, one of the consequences of the lack of data on cross-country licensing flows is that most of the existing literature has focused on technology transfers from MNEs headquartered in one country (e.g., the US) to their affiliates in the rest of the world. Therefore, it is worthwhile to look at the relationship between IP protection and inward licensing for the subpopulation of unaffiliated firms. In this dataset, we can distinguish firms with full domestic ownership, which represent $89 \%$ of the sample and are unaffiliated by definition, from firms with full or partial foreign ownership, which include fully owned subsidiaries and affiliates of MNEs. ${ }^{12}$

Table 5 presents summary statistics of all country-level and firm-level variables by ownership type, where columns (1) and (2) represent unaffiliated and affiliated firms respectively; column (3), by definition, is the same as column (3) in Table 2; and column (4) is a paired samples statistic with standard errors clustered by country for the null hypothesis that the group means are equal for unaffiliated and affiliated firms.

Table 5: Summary Statistics of Unaffiliated versus Affiliated Firms

\begin{tabular}{|c|c|c|c|c|}
\hline & $\begin{array}{l}\text { Domestic } \\
\text { Ownership }\end{array}$ & $\begin{array}{c}\text { Full or Partial } \\
\text { Foreign } \\
\text { Ownership }\end{array}$ & Total & t-statistic \\
\hline Index of Patent Rights & $\begin{array}{c}0.655 \\
(0.050)\end{array}$ & $\begin{array}{r}0.729 \\
(0.211)\end{array}$ & $\begin{array}{c}0.657 \\
(0.054)\end{array}$ & $-3.855^{* * *}$ \\
\hline Human capital & $\begin{array}{c}0.675 \\
(0.094)\end{array}$ & $\begin{array}{c}0.844 \\
(0.326)\end{array}$ & $\begin{array}{r}0.679 \\
(0.102)\end{array}$ & $-9.038^{* * *}$ \\
\hline Trade ( $\%$ of GDP) & $\begin{array}{c}0.428 \\
(0.088)\end{array}$ & $\begin{array}{c}0.456 \\
(0.503)\end{array}$ & $\begin{array}{c}0.429 \\
(0.097)\end{array}$ & -0.381 \\
\hline Foreign direct investment ( $\%$ of GDP) & $\begin{array}{l}0.018 \\
(0.008)\end{array}$ & $\begin{array}{c}0.024 \\
(0.047)\end{array}$ & $\begin{array}{l}0.018 \\
(0.009)\end{array}$ & $-2.635^{* *}$ \\
\hline $\begin{array}{l}\text { Indicator for use of technology licensed from a } \\
\text { foreign company }\end{array}$ & $\begin{array}{c}0.176 \\
(0.363)\end{array}$ & $\begin{array}{l}0.482 \\
(1.122)\end{array}$ & $\begin{array}{c}0.183 \\
(0.387)\end{array}$ & $-6.435^{* * *}$ \\
\hline Firm size $(\mathrm{FTEs} / 1,000)$ & $\begin{array}{r}0.025 \\
(0.134)\end{array}$ & $\begin{array}{l}0.464 \\
(2.834)\end{array}$ & $\begin{array}{c}0.035 \\
(0.242)\end{array}$ & $-2.289^{* *}$ \\
\hline Indicator for publicly listed company & $\begin{array}{c}0.005 \\
(0.069)\end{array}$ & $\begin{array}{c}0.167 \\
(0.838)\end{array}$ & $\begin{array}{c}0.009 \\
(0.094)\end{array}$ & $-2.117^{* *}$ \\
\hline Indicator for privately held, LLC & $\begin{array}{l}0.173 \\
(0.360)\end{array}$ & $\begin{array}{c}0.734 \\
(0.992)\end{array}$ & $\begin{array}{c}0.185 \\
(0.388)\end{array}$ & $-11.624^{* * *}$ \\
\hline Indicator for sole proprietorship & $\begin{array}{c}0.769 \\
(0.402)\end{array}$ & $\begin{array}{l}0.037 \\
(0.425)\end{array}$ & $\begin{array}{c}0.753 \\
(0.431)\end{array}$ & $6.071^{* * *}$ \\
\hline Indicator for partnership/limited partnership & $\begin{array}{c}0.051 \\
(0.209)\end{array}$ & $\begin{array}{c}0.053 \\
(0.505)\end{array}$ & $\begin{array}{c}0.051 \\
(0.219)\end{array}$ & -0.141 \\
\hline Indicator for other legal status & $\begin{array}{c}0.002 \\
(0.047)\end{array}$ & $\begin{array}{c}0.008 \\
(0.202)\end{array}$ & $\begin{array}{r}0.003 \\
(0.051)\end{array}$ & -1.271 \\
\hline Fraction with private domestic ownership & $\begin{array}{c}0.996 \\
(0.057)\end{array}$ & $\begin{array}{c}0.260 \\
(0.729)\end{array}$ & $\begin{array}{r}0.980 \\
(0.133)\end{array}$ & $8.474^{* * *}$ \\
\hline Fraction with private foreign ownership & - & - & $\begin{array}{r}0.016 \\
(0.118)\end{array}$ & - \\
\hline Fraction with government/state ownership & $\begin{array}{r}0.000 \\
(0.014) \\
\end{array}$ & $\begin{array}{c}0.012 \\
(0.097)\end{array}$ & $\begin{array}{c}0.001 \\
(0.016)\end{array}$ & -1.532 \\
\hline
\end{tabular}

continued on next page

12 Per the OECD Benchmark Definition of Foreign Direct Investment, which sets the world standard for collecting direct investment statistics, the accepted threshold for an FDI relationship is 10\%. That is, the foreign investor must own at least $10 \%$ of the voting stock or ordinary shares of the investee company. 
Table 5 continued

\begin{tabular}{lcccc}
\hline & Full or Partial & & \\
& Domestic & Foreign & & \\
& Ownership & Ownership & Total & t-statistic \\
\hline Fraction with other ownership & 0.004 & 0.013 & 0.004 & -1.113 \\
& $(0.055)$ & $(0.094)$ & $(0.058)$ & \\
Firm age (years/100) & 0.175 & 0.336 & 0.179 & $-3.188^{* * *}$ \\
& $(0.105)$ & $(0.515)$ & $(0.117)$ & \\
Fraction of domestic sales & 0.983 & 0.840 & 0.980 & $4.963^{* * *}$ \\
& $(0.090)$ & $(0.611)$ & $(0.104)$ & \\
Fraction of indirect exports & 0.006 & 0.034 & 0.006 & $-5.881^{* * *}$ \\
& $(0.049)$ & $(0.296)$ & $(0.055)$ & \\
Fraction of direct exports & 0.011 & 0.127 & 0.014 & $-4.367^{* * *}$ \\
& $(0.074)$ & $(0.545)$ & $(0.086)$ & \\
Indicator for direct importer of inputs & 0.051 & 0.542 & 0.062 & $-4.835^{* * *}$ \\
& $(0.211)$ & $(1.119)$ & $(0.242)$ & \\
Fraction of fixed assets financed with internal & 0.397 & 0.488 & 0.399 & $-5.826^{* * *}$ \\
funds/retained earnings & $(0.449)$ & $(1.020)$ & $(0.471)$ & \\
Fraction of fixed assets financed with & 0.043 & 0.137 & 0.045 & $-2.966^{* * *}$ \\
bank loans & $(0.169)$ & $(0.644)$ & $(0.181)$ & \\
Fraction of fixed assets financed with & 0.025 & 0.045 & 0.026 & $-2.979^{* * *}$ \\
trade credit & $(0.124)$ & $(0.367)$ & $(0.131)$ & \\
Fraction of fixed assets financed with owners' & 0.003 & 0.020 & 0.003 & $-3.304^{* * *}$ \\
contribution/new equity shares & $(0.040)$ & $(0.267)$ & $(0.045)$ & \\
Fraction of fixed assets financed with & 0.017 & 0.015 & 0.017 & 0.334 \\
other means & $(0.090)$ & $(0.230)$ & $(0.095)$ & \\
Number of observations & 29,650 & 3,722 & 33,372 & \\
\hline
\end{tabular}

FTEs = full-time equivalents, GDP = gross domestic product, $L L C=$ limited liability company .

Notes: Standard deviations in parentheses. The t-statistics represent a paired samples statistic with standard errors clustered by country for the null hypothesis that the group means are equal for firms without any foreign technology licensing, and for firms with foreign technology licensing. * **, and *** denote statistical significance at the $10 \%, 5 \%$, and $1 \%$ levels, respectively.

a The exact breakdown of directly and indirectly imported production inputs is not available.

Source: Author's calculations.

Straightaway, it is clear that the differences in means are highly statistically significant across the majority of variables. Firms with full or partial foreign ownership (i.e., affiliated firms) tend to be located in countries with stronger IP protection, and higher levels of human capital and FDI. Affiliated firms are on average larger, older companies; they are more likely to be publicly listed or limited liability companies, to be export oriented, and to have better access to finance.

Table 6 replicates columns (4) and (5) in Table 4 for the subpopulations of unaffiliated and affiliated firms. For the former category, the coefficient for IPR is statistically insignificant. For firms with full or partial foreign ownership, our preferred specification in column (4) reveals that going from no IP protection to maximum IP protection is associated with an increase in the predicted probability of being a licensee of $65 \%$, which translates into a $13 \%$ increase for a one-unit change in the raw IPR. The coefficient is statistically significant at the $2 \%$ level. The specification with country fixed effects in column (5) yields a coefficient that is similar in magnitude, but is only significant at the $10 \%$ level. The magnitude and significance of the other country-level and firm-level covariates is consistent with Table 4. 


\section{Table 6: Linear Probability Model of the Relationship between IP Protection and Foreign Technology Licensing for the Subpopulations of Unaffiliated versus Affiliated Firms}

\begin{tabular}{|c|c|c|c|c|}
\hline & \multicolumn{2}{|c|}{ Unaffiliated Firms } & \multicolumn{2}{|c|}{ Affiliated Firms } \\
\hline & $\begin{array}{l}\text { All Country-Level } \\
\text { and Firm-Level } \\
\text { Controls } \\
(4)\end{array}$ & $\begin{array}{l}\text { Country Fixed } \\
\text { Effects and Firm- } \\
\text { Level Controls } \\
\text { (5) }\end{array}$ & $\begin{array}{l}\text { All Country-Level } \\
\text { and Firm-Level } \\
\text { Controls } \\
(4)\end{array}$ & $\begin{array}{l}\text { Country Fixed } \\
\text { Effects and Firm- } \\
\text { Level Controls } \\
\text { (5) }\end{array}$ \\
\hline \multirow[t]{2}{*}{ Index of Patent Rights (IPR) } & 0.050 & 0.060 & $0.646^{* *}$ & $0.561^{*}$ \\
\hline & $(0.103)$ & $(0.183)$ & $(0.241)$ & $(0.329)$ \\
\hline \multirow{2}{*}{ Survival to age 65 , male (\% of cohort) } & $-0.220^{* * *}$ & - & $-0.682^{* *}$ & - \\
\hline & $(0.067)$ & & $(0.333)$ & \\
\hline \multirow[t]{2}{*}{ Trade (\% of GDP) } & $0.094^{* *}$ & - & 0.022 & - \\
\hline & $(0.045)$ & & $(0.120)$ & \\
\hline \multirow[t]{2}{*}{ Foreign direct investment (\% of GDP) } & -0.341 & - & $-0.896^{*}$ & - \\
\hline & $(0.302)$ & & $(0.475)$ & \\
\hline \multirow{2}{*}{ Firm size (FTEs/1,000) } & $0.105^{* * *}$ & $0.109^{* * *}$ & $0.127^{* * *}$ & $0.140^{* * *}$ \\
\hline & $(0.020)$ & $(0.016)$ & $(0.014)$ & $(0.012)$ \\
\hline \multirow[t]{2}{*}{ Firm size (FTEs/1,000) squared } & $-0.005^{* *}$ & $-0.005^{* *}$ & $-0.008^{* * *}$ & $-0.008^{* * *}$ \\
\hline & $(0.002)$ & $(0.002)$ & $(0.001)$ & $(0.001)$ \\
\hline \multirow[t]{2}{*}{ Fraction with private foreign ownership } & - & - & $0.301^{* * *}$ & $0.320^{* * *}$ \\
\hline & & & $(0.088)$ & $(0.083)$ \\
\hline \multirow{2}{*}{$\begin{array}{l}\text { Fraction with government/state } \\
\text { ownership }\end{array}$} & -0.029 & $-0.068^{*}$ & 0.240 & 0.147 \\
\hline & $(0.045)$ & $(0.036)$ & $(0.520)$ & $(0.544)$ \\
\hline \multirow[t]{2}{*}{ Fraction with other ownership } & $0.575^{* * *}$ & $0.580^{* * *}$ & -0.176 & -0.148 \\
\hline & $(0.115)$ & $(0.113)$ & $(0.574)$ & $(0.718)$ \\
\hline \multirow[t]{2}{*}{ Firm age (years/100) } & $0.406^{* * *}$ & $0.420^{* * *}$ & $0.617^{* * *}$ & $0.430^{* *}$ \\
\hline & $(0.103)$ & $(0.097)$ & $(0.172)$ & $(0.176)$ \\
\hline \multirow[t]{2}{*}{ Firm age squared } & $-0.438^{* * *}$ & $-0.453^{* * *}$ & $-0.712^{* * *}$ & $-0.568^{* *}$ \\
\hline & $(0.117)$ & $(0.113)$ & $(0.263)$ & $(0.224)$ \\
\hline \multirow[t]{2}{*}{ Fraction of indirect exports } & 0.150 & 0.155 & -0.126 & -0.100 \\
\hline & $(0.135)$ & $(0.138)$ & $(0.133)$ & $(0.122)$ \\
\hline \multirow[t]{2}{*}{ Fraction of direct exports } & 0.018 & 0.020 & -0.056 & -0.070 \\
\hline & $(0.035)$ & $(0.034)$ & $(0.125)$ & $(0.146)$ \\
\hline \multirow[t]{2}{*}{ Indicators for direct importer of inputs } & $0.083^{* * *}$ & $0.086^{* * *}$ & 0.068 & $0.157^{* *}$ \\
\hline & $(0.005)$ & $(0.005)$ & $(0.053)$ & $(0.071)$ \\
\hline \multirow{2}{*}{$\begin{array}{l}\text { Fraction of fixed assets financed with } \\
\text { bank loans }\end{array}$} & 0.035 & 0.039 & 0.172 & $0.213^{*}$ \\
\hline & $(0.024)$ & $(0.024)$ & $(0.119)$ & $(0.119)$ \\
\hline \multirow{2}{*}{$\begin{array}{l}\text { Fraction of fixed assets financed with } \\
\text { trade credit }\end{array}$} & $0.102^{* *}$ & $0.107^{* *}$ & -0.018 & 0.028 \\
\hline & $(0.046)$ & $(0.045)$ & $(0.069)$ & $(0.077)$ \\
\hline \multirow{2}{*}{$\begin{array}{l}\text { Fraction of fixed assets financed with owners' } \\
\text { contribution/new equity shares }\end{array}$} & 0.050 & $0.052^{*}$ & 0.297 & $0.381^{*}$ \\
\hline & $(0.031)$ & $(0.029)$ & $(0.220)$ & $(0.214)$ \\
\hline \multirow{2}{*}{$\begin{array}{l}\text { Fraction of fixed assets financed with } \\
\text { other means }\end{array}$} & -0.005 & -0.009 & $0.083^{*}$ & 0.058 \\
\hline & $(0.050)$ & $(0.049)$ & $(0.048)$ & $(0.043)$ \\
\hline \multirow[t]{2}{*}{ Intercept } & 0.010 & $-0.268^{* * *}$ & -0.169 & $-0.351^{*}$ \\
\hline & $(0.098)$ & $(0.074)$ & $(0.185)$ & $(0.181)$ \\
\hline Number of observations & 29,650 & 29,650 & 3,722 & 3,722 \\
\hline Country fixed effects & $\mathrm{N}$ & Y & $\mathrm{N}$ & Y \\
\hline Sector fixed effects & Y & Y & Y & Y \\
\hline Year fixed effects & Y & Y & Y & Y \\
\hline Legal status fixed effects & Y & Y & Y & Y \\
\hline
\end{tabular}

FTEs = full-time equivalents, GDP = gross domestic product, IP = intellectual property.

Notes: Standard errors of the means clustered by country in parentheses. Columns (4) include sector year fixed effects, along with a firm's legal status of publicly listed company, privately held/limited liability company, and partnership/limited partnership, with sole proprietorship being the excluded category. Columns (5) include sector, country, year, and legal status fixed effects. ${ }^{*},{ }^{* *}$, and ${ }^{* * *}$ denote statistical significance at the $10 \%$, $5 \%$, and $1 \%$ levels, respectively.

Source: Author's calculations. 
Branstetter, Fisman, and Foley (2006) found that IP reform increased the log of the value of royalty payments to the parent firm by $17 \%$, which rose to $34 \%$ for affiliates of parents that made more extensive use of patents in the US in the 4 years prior to the reform. Wakasugi and Ito (2007) estimated the elasticity of technology transfer with respect to the IPR at $96 \%$, with statistical significance at the $1 \%$ level. Therefore, the results in Table 6 are in line with the findings in Branstetter, Fisman, and Foley (2006) and Wakasugi and Ito (2007) for affiliated firms, i.e., a positive and significant relationship between IP protection and licensing. However, they also show that there is no significant correlation between IP protection and inward licensing for unaffiliated firms.

\section{B. Development Stage}

It is easy to envision a loop of causality between IP protection and development stage: strong IP rights are presented by proponents as a contributor to economic growth but, at the same time, IP rights tend to strengthen as economic development and income rises (Maskus and Penubarti 1995). The rationale behind the latter causal relationship is intuitive: as technological sophistication increases in an economy, innovators demand stronger protection for their ideas; at the same time, as income rises, consumers demand more quality and more variety, also leading to an increase in supply of IP rights. That raises the question whether the relationship between IP protection and licensing is also contingent on a country's income level, seeing as the IPR tends to increase with income.

Intuitively, we would expect that strengthening IP rights would have no impact on foreign technology licensing in economies characterized by fragile institutions, inadequate infrastructure, low levels of human capital, and weak internal demand. On the other hand, industrializing economies can use comprehensive IP protection, combined with an educated labor force, growing infrastructure, political stability, and a vibrant domestic market to attract FDI, establish R\&D collaborations, and support domestic innovation.

Figure 2 presents three scatterplots of the proportion of licensees by country by year versus the IPR, where countries are divided into upper-middle-income countries, lower-middle-income countries, and low-income countries, per the World Bank classification. Superimposed on each scatterplot is the restricted cubic spline smooth of the proportion of licensees given the level of IPR. Figure 2 indicates no clear relationship between IPR and proportion of licensees. The negative slopes for the two middleincome country groupings seem to be driven by a few outliers. Nonetheless, a significant relationship may arise with the addition of country-level and firm-level controls.

Table 7 replicates columns (4) and (5) in Tables 4 and 6, except that the IPR is interacted with an indicator of a country's income classification, with upper-middle-income country being the excluded category. The results are presented in Panel A for the pooled sample, followed by the subpopulations of unaffiliated and affiliated firms. Because of the interaction between IPR and income classification, the coefficient for the IPR in Table 7 represents the relationship between IP protection and foreign technology licensing in upper-middle-income countries (the excluded category). The odd columns contain our preferred specification, whereas the even columns contain the specification with country fixed effects. Panel B displays statistical tests of the categorical-by-continuous interaction: in particular, we present the results of a Wald test of the overall significance of the interaction, as well as point estimates and $p$-values for the linear combinations of the main coefficient for IPR with the relevant interaction terms. 


\section{Figure 2: Restricted Cubic Spline Smooth of Proportion of Licensees Given the Level of IPR}

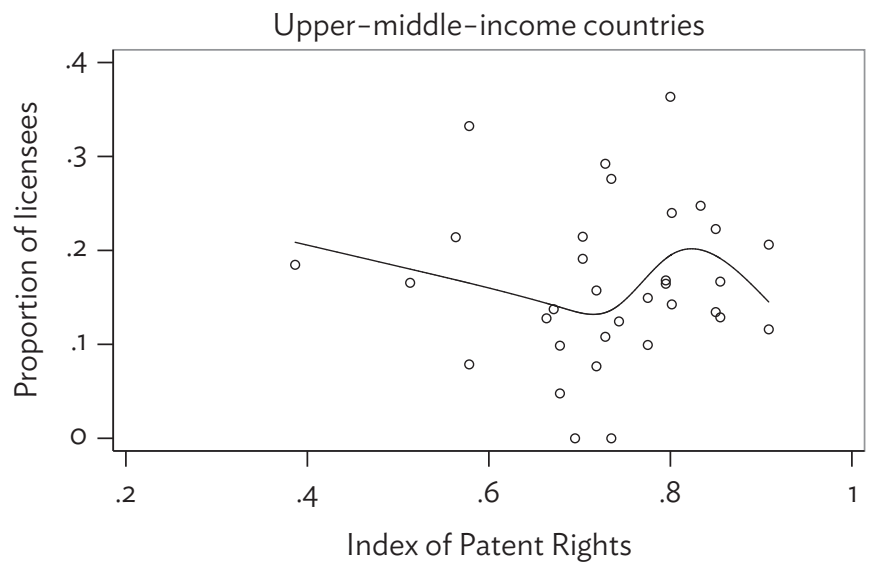

knots 5; R² 0.1027; RMSE .0847

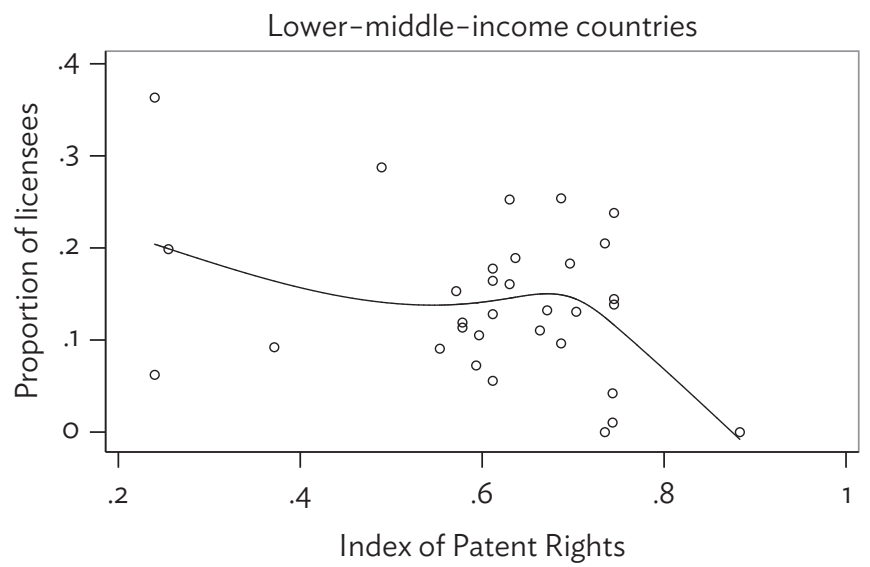

knots 5; R² 0.1763; RMSE .081

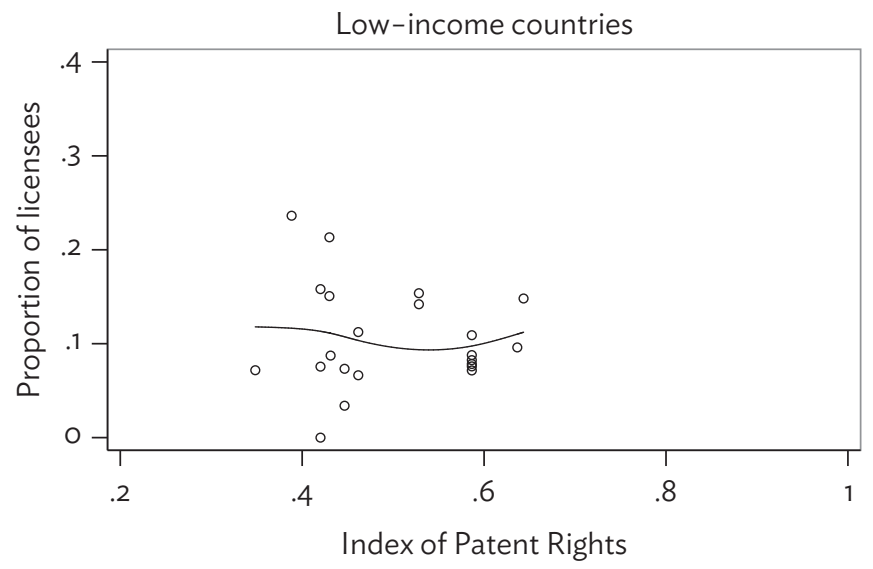

knots 5; R² 0.0202; RMSE .0607

$I P R=$ Index of Patent Rights, RMSE = root-mean-squared error. Source: Author's calculations. 
The first line of Panel A indicates that the relationship between IP protection and foreign technology licensing in upper-middle-income countries is positive and significant at the $1 \%$ level for the pooled sample. The first column in Table 7 shows that going from no IP protection to maximum IP protection is associated with an increase in the predicted probability of being a licensee of $47 \%$ for firms operating in upper-middle-income countries. The analysis of the subpopulations of affiliated and unaffiliated firms confirms the findings, although the coefficients for affiliated firms appear to be noisier.

The interaction between IPR and indicator for lower-middle-income country is negative, statistically significant, and larger than the coefficient for upper-middle-income countries for the pooled sample and both subsamples. However, the linear combinations of coefficients are statistically insignificant. Lastly, the interaction between IPR and indicator for low-income country is not significantly different from zero for the pooled sample and both subsamples.

The results in Table 7 suggest that tighter IP rights may have a positive impact on technology adoption only if a series of preconditions are met. Economies at early stages of development often lack not only the institutional framework, but also the infrastructure, and the human capital required for successful adoption of foreign technologies. As economies progress in their development, expanded and strengthened IP protection is more likely to encourage licensing of foreign technology, both affiliated and unaffiliated.

\section{Firm-Level Endogeneity}

In a firm-level cross-sectional setting, there may still be reverse causality if firms have sufficient influence on policy makers to set IP protection at their desired level.

In the absence of a valid instrument, the only way to address the issue of endogeneity is by exploiting the firm information contained in the dataset. What types of firms are more likely to successfully lobby their governments to obtain their desired level of IP protection?

First, if a country is proactively pursuing FDI, its government is likely to be sensitive to the foreign investors' demands. In fact, Table 6 presents evidence that intrafirm technology transfer from parent companies to their subsidiaries is driving the results for the pooled sample. Second, it is possible that large firms have more political influence because they are major employers, and because they have more resources than small and medium enterprises to lobby their central governments. ${ }^{13}$ Finally, if a country is pursuing a trade policy aimed at boosting exports, firms that export all or part of their output may be able to influence the level of IP protection in their country of operation.

13 The Enterprise Surveys define large firms as having 100 or more employees. 
Table 7: Linear Probability Model of the Relationship between IP Protection and Foreign Technology Licensing by Income Level

\begin{tabular}{|c|c|c|c|c|c|c|}
\hline & \multicolumn{2}{|c|}{ Pooled Sample } & \multicolumn{2}{|c|}{ Unaffiliated Firms } & \multicolumn{2}{|c|}{ Affiliated Firms } \\
\hline & $\begin{array}{l}\text { All Country- } \\
\text { Level and Firm- } \\
\text { Level Controls } \\
\text { (4) }\end{array}$ & $\begin{array}{c}\text { Country Fixed } \\
\text { Effects Only } \\
\text { (5) }\end{array}$ & $\begin{array}{l}\text { All Country-Level } \\
\text { and Firm-Level } \\
\text { Controls } \\
\text { (4) }\end{array}$ & $\begin{array}{l}\text { Country Fixed } \\
\text { Effects Only } \\
\text { (5) }\end{array}$ & $\begin{array}{l}\text { All Country-Level } \\
\text { and Firm-Level } \\
\text { Controls } \\
(4)\end{array}$ & $\begin{array}{c}\text { Country Fixed } \\
\text { Effects Only } \\
(5)\end{array}$ \\
\hline & \multicolumn{6}{|c|}{ (a) Regression results } \\
\hline Index of Patent Rights (IPR) & $0.465^{* * *}$ & 0.513 & $0.375^{* * *}$ & 0.361 & $1.069^{* *}$ & 0.394 \\
\hline & $(0.110)$ & $(0.350)$ & $(0.093)$ & $(0.400)$ & $(0.452)$ & $(0.613)$ \\
\hline Lower-middle-income country & $0.642^{* * *}$ & 0.113 & $0.550^{* * *}$ & 0.126 & $1.389^{*}$ & -0.291 \\
\hline & $(0.188)$ & $(0.247)$ & $(0.180)$ & $(0.261)$ & $(0.695)$ & $(0.422)$ \\
\hline Low-income country & 0.195 & 0.199 & $0.311^{* *}$ & 0.198 & 0.591 & -0.210 \\
\hline & $(0.173)$ & $(0.353)$ & $(0.150)$ & $(0.327)$ & $(0.371)$ & $(0.616)$ \\
\hline IPR*lower-middle-income country & $-0.793^{* * *}$ & -0.232 & $-0.662^{* *}$ & -0.252 & $-1.811^{*}$ & 0.164 \\
\hline & $(0.270)$ & $(0.326)$ & $(0.256)$ & $(0.345)$ & $(0.925)$ & $(0.558)$ \\
\hline IPR*low-income country & -0.175 & -0.600 & -0.363 & -0.603 & $-1.059^{*}$ & -0.781 \\
\hline & $(0.294)$ & $(0.544)$ & $(0.258)$ & $(0.478)$ & $(0.569)$ & $(0.975)$ \\
\hline Number of observations & 33,372 & 33,372 & 29,650 & 29,650 & 3,722 & 3,722 \\
\hline Country fixed effects & $\mathrm{N}$ & Y & $\mathrm{N}$ & Y & $\mathrm{N}$ & Y \\
\hline Sector fixed effects & Y & Y & Y & Y & Y & Y \\
\hline Year fixed effects & Y & Y & Y & Y & Y & Y \\
\hline \multirow[t]{2}{*}{ Legal status fixed effects } & Y & Y & Y & Y & Y & Y \\
\hline & \multicolumn{6}{|c|}{ (b) Statistical tests of the interaction } \\
\hline Wald test of overall significance & & & & & & \\
\hline f-statistic & $4.584^{* *}$ & 0.609 & $4.352^{* *}$ & 0.808 & $2.580^{*}$ & 0.690 \\
\hline$p$-value & 0.016 & 0.549 & 0.019 & 0.453 & 0.088 & 0.507 \\
\hline \multicolumn{7}{|l|}{ Linear combinations of coefficients } \\
\hline Upper-middle-income country & $0.465^{* * *}$ & 0.513 & $0.375^{* * *}$ & 0.361 & $1.069^{* *}$ & 0.394 \\
\hline p-value & 0.000 & 0.150 & 0.000 & 0.373 & 0.023 & 0.524 \\
\hline Lower-middle-income country & -0.329 & 0.281 & -0.287 & 0.108 & -0.742 & $0.558^{* * *}$ \\
\hline$p$-value & 0.208 & 0.137 & 0.252 & 0.469 & 0.295 & 0.019 \\
\hline Low-income country & 0.290 & -0.087 & 0.012 & -0.242 & 0.011 & -0.388 \\
\hline$p$-value & 0.372 & 0.831 & 0.967 & 0.448 & 0.979 & 0.648 \\
\hline
\end{tabular}

$\mathrm{IP}=$ intellectual property.

Notes: Standard errors of the means clustered by country in parentheses. Columns (4) include sector and year fixed effects, along with a firm's legal status of publicly listed company, privately held/limited liability company, and partnership/limited partnership, with sole proprietorship being the excluded category. Columns (5) include sector, country, year, and legal status fixed effects. ${ }^{*},{ }^{* *}$, and ${ }^{* * *}$ denote statistical significance at the $10 \%, 5 \%$, and $1 \%$ levels, respectively.

Source: Author's calculations. 
In order to address the potential firm-level endogeneity, Table 8 replicates the models in Tables 6 and 7, respectively, focusing on the subpopulation of unaffiliated small and medium enterprises with domestic sales, which represents roughly $94 \%$ of the entire sample. ${ }^{14}$ The first two columns in Table 8 are in line with the findings for unaffiliated firms in Table 6 . The last two columns in Table 8, instead, confirm the results for unaffiliated firms in Table 7. Thus, the results are robust to the exclusion of potential sources of firm-level endogeneity.

Table 8: Linear Probability Model of the Relationship between IP Protection and Foreign Technology Licensing for the Subpopulations of Unaffiliated Small and Medium Enterprises with Domestic Sales

\begin{tabular}{|c|c|c|c|c|}
\hline & $\begin{array}{l}\text { All Country- } \\
\text { Level and Firm- } \\
\text { Level Controls } \\
\text { (4) }\end{array}$ & $\begin{array}{l}\text { Country Fixed } \\
\text { Effects and } \\
\text { Firm-Level } \\
\text { Controls } \\
\text { (5) }\end{array}$ & $\begin{array}{l}\text { All Country- } \\
\text { Level and Firm- } \\
\text { Level Controls } \\
\text { (4) }\end{array}$ & $\begin{array}{l}\text { Country Fixed } \\
\text { Effects and } \\
\text { Firm-Level } \\
\text { Controls } \\
\text { (5) }\end{array}$ \\
\hline & \multicolumn{4}{|c|}{ (a) Regression results } \\
\hline \multirow[t]{2}{*}{ Index of Patent Rights (IPR) } & 0.098 & $0.270^{*}$ & $0.435^{* * *}$ & 0.495 \\
\hline & $(0.121)$ & $(0.147)$ & $(0.137)$ & $(0.350)$ \\
\hline \multirow[t]{2}{*}{ Lower-middle-income country } & - & - & $0.545^{* *}$ & 0.052 \\
\hline & & & $(0.211)$ & $(0.242)$ \\
\hline \multirow[t]{2}{*}{ Low-income country } & - & - & $0.298^{*}$ & 0.369 \\
\hline & & & $(0.166)$ & $(0.293)$ \\
\hline \multirow[t]{2}{*}{ IPR*lower-middle-income country } & - & - & $-0.638^{* *}$ & -0.139 \\
\hline & & & $(0.302)$ & $(0.313)$ \\
\hline \multirow{2}{*}{ IPR*Iow-income country } & - & - & -0.320 & $-0.884^{* *}$ \\
\hline & & & $(0.269)$ & $(0.418)$ \\
\hline Number of observations & 18,922 & 18,922 & 18,922 & 18,922 \\
\hline Country fixed effects & $\mathrm{N}$ & Y & $\mathrm{N}$ & Y \\
\hline Sector fixed effects & Y & Y & Y & Y \\
\hline Year fixed effects & Y & Y & Y & Y \\
\hline \multirow[t]{2}{*}{ Legal status fixed effects } & Y & Y & Y & Y \\
\hline & \multicolumn{4}{|c|}{ (b) Statistical tests of the interaction } \\
\hline \multicolumn{5}{|l|}{ Wald test of overall significance } \\
\hline f-statistic & - & - & $2.653^{*}$ & $2.887^{*}$ \\
\hline$p$-value & & & 0.083 & 0.067 \\
\hline \multicolumn{5}{|l|}{ Linear combinations of coefficients } \\
\hline Upper-middle-income country & - & - & $0.435^{* * *}$ & 0.495 \\
\hline$p$-value & & & 0.003 & 0.164 \\
\hline Lower-middle-income country & - & - & -0.203 & $0.356^{* * *}$ \\
\hline$p$-value & & & 0.457 & 0.002 \\
\hline Low-income country & - & - & 0.115 & -0.389 \\
\hline$p$-value & & & 0.690 & 0.243 \\
\hline
\end{tabular}

IP = intellectual property.

Notes: Standard errors of the means clustered by country in parentheses. Columns (4) include sector and year fixed effects, along with a firm's legal status of publicly listed company, privately held / limited liability company, and partnership / limited partnership, with sole proprietorship being the excluded category. Columns (5) include sector, country, year, and legal status fixed effects. ${ }^{*},{ }^{* *}$, and ${ }^{* *}$ denote statistical significance at the $10 \%, 5 \%$, and $1 \%$ levels, respectively.

Source: Author's calculations.

14 For an overview of the composition of this subsample, refer to Table A.3 in the Appendix. 


\section{CONCLUSION}

The relationship between intellectual property protection and cross-country technology licensing has been a widely debated issue since IP made its début in international trade with the TRIPS Agreement. Theoretical predictions are ambiguous, and sensitive to the assumptions underlying a specific model; empirical investigations are plagued by the scarcity of data quantifying cross-country licensing flows.

In this paper, we assess whether stronger IP protection is associated with an increase in licensing of foreign technology in developing countries, thus moving the focus from the licensors to the licensees. While the previous literature relied on proxies for technology transfer, we have a stratified sample that is representative of the whole population of nonagricultural private firms in 42 developing countries with information on licensing status, sector of activity, size, ownership, and other characteristics. We use the Index of Patent Rights, representing the completeness of a country's legal framework for intellectual property, to measure the strength of country-level IP protection.

The evidence leads to two conclusions: first, there is a positive and significant relationship between IP protection and foreign technology licensing only for affiliated firms, consistent with the existing empirical literature, whereas we find no relationship between IP protection and licensing for unaffiliated firms. Second, the environment in which a firm operates seems to moderate the relationship of IP protection and firm-level technology licensing: we find that tighter IP protection is associated with an increase in licensing activity only for firms operating in upper-middle-income countries, whereas there is at best no significant correlation between the degree of IP protection and technology licensing for firms operating in lower-middle-income and low-income countries. Finally, we find that firm characteristics are strong predictors of technology licensing status: firms that are licensees are significantly different from nonlicensees in legal status, ownership structure, age, and access to finance.

Our preferred specification includes a wide array of firm-level controls, sector and year fixed effects, as well as three country-level covariates that are potentially correlated with both the outcome of interest and the independent variable of interest. We also present an alternative specification with country, sector, and year fixed effects, along with the same set of firm-level controls, which yields remarkably consistent results if not for the fact that they are noisier, since there is little variation in the IPR over time.

In the absence of a valid instrument, we address the potential firm-level endogeneity by considering the types of firms that are more likely to have lobbying power on their governments (namely, large firms, foreign investors, and exporters), and then exclude these firms from the sample. The qualitative results are, again, largely maintained.

All in all, our empirical strategy alleviates, but does not eliminate the possibility of omitted variable bias. Therefore, our findings cannot be interpreted as necessarily causal.

As mentioned in section I, in the theoretical literature, the effect of expanded and strengthened IP protection on the broader economy depends on whether the reforming country is "rewarded" with an increase in FDI that outweighs the decline in imitative activity. Since FDI recipients are generally open economies with skilled workforces and good growth prospects, upper-middle-income countries that reform IP rights are likely to enjoy an increase in licensing, in the form of intrafirm technology transfers from foreign parent companies to their local affiliates, as theorized by Lai (1998). Lower-middle-income and low-income economies, on the other hand, are less attractive to foreign investors, and therefore are less likely to receive an increase in FDI to compensate them for the fact that access to technology has 
become costlier for local unaffiliated firms, which is in line with the findings in Helpman (1993). The natural conclusion to this line of reasoning would be that strengthened IP protection does not have growth-promoting effects for developing economies; rather, it is a consequence of economic growth.

It is perhaps not surprising that there are no clear predictions of the effect of IP protection on technology transfer in the theoretical literature: our results suggest that the relationship varies by country and firm characteristics, and therefore there is no one-size-fits-all solution when it comes to setting the "optimal" level of IP protection for technology transfer. Since developing countries depend on the adoption and adaptation of foreign technology to drive local innovation, a more focused approach to IP is needed to address the technological lag between the developed and developing world. That means shifting the focus of the debate away from the strength of IP rights to the appropriate types of IP rights for economic development (Kim et al. 2012).

One limitation of our study is that, due to the binary nature of the dependent variable, we can only capture the extensive margin of licensing activity in response to IP policy changes. We cannot capture the intensive margin, that is firms reducing or increasing the amount of licensing contracts they enter into. However, the common approach in the existing literature that relies solely on royalty payments has limitations, too, as discussed in section II. It is also worth reiterating that data on developing countries - especially least developed countries - is difficult to come by. In fact, previous studies on the impact of IP reform in developing countries focused on emerging markets, a specific subset for which data is relatively more abundant; but emerging markets experience levels of growth and industrialization that set them apart from the rest of the developing world. This dataset, despite its limitations, contains firms operating in the most diverse economic, sociocultural, and geographical contexts.

Currently, the Enterprise Surveys only record whether firms have successfully entered into a licensing agreement with a foreign entity. We have no information on the number of contracts, the corresponding royalty payments, or the countries of origin of licensed technology; neither do we know which firms tried to license, but were unsuccessful. If future business surveys could collect this kind of information, it would certainly draw a more detailed picture of the barriers to technology adoption faced by firms in the developing world.

An interesting area to explore for future research is the potential indirect effects of tighter IP protection on cross-country technology adoption. Since arms-length licensing is not the only channel for technology transfer, firms may react to the policy change by seeking alternative channels to acquire foreign technology. Unfortunately, such an investigation would require a wealth of data that is currently not available. 


\section{APPENDIX: POLICY BACKGROUND}

The term "intellectual property" refers to the legal rights resulting from intellectual activity in the industrial, scientific, literary, and artistic fields. It is divided into two categories: literary and artistic works, protected by copyright; and industrial property, which includes inventions (patents), trademarks, industrial designs, and geographic indications of source (WIPO 2004). Arms-length licensing is a contract under which a patent holder (the licensor) grants a license to a licensee, to authorize the use of a patented invention in exchange for compensation.

In 1474 the Venetian Republic enacted the first properly developed patent law, with the explicit purpose of encouraging technological advancement. Besides granting exclusivity to the inventor of a machine or a process, it provided for destruction of infringing devices and payment of a fee to the inventor (Schaafsma 1997). In England, the Statute of Monopolies of 1623 was enacted to end the abuse of the royal prerogative in issuing patent monopolies, rather than protect the rights of inventors (Mossoff 2001). In the US, the Patent Act was passed in 1790. At this stage, IP protection was based on the principle of territoriality, i.e., the rights did not extend beyond the territory of the sovereign who granted them; therefore, patent holders faced a classic free-riding problem (Braithwaite and Drahos 2000, Ch. 7).

In the mid-19th century, IP protection began to acquire an international dimension: the existence of national patent systems was a violation of the principles of free trade, as the royalties that licensors paid to licensees varied across borders. States that were affected by the free-riding problem began to negotiate bilateral treaties with other states, while those who were benefiting from the positive externality remained isolationist (ibid.). This phase of bilateral treaty making was based on a strategy of reciprocity: inventors from country $A$ would enjoy the same degree of protection in country $B$ as inventors from country B did in country A (Johns 2009, Ch. 10).

The final incentive to serious international cooperation on intellectual property came in 1873, when the Government of the Austro-Hungarian Empire organized an international exhibition of inventions in Vienna, but foreign inventors were reluctant to participate on account of the inadequate protection offered to their intellectual property. That same year, the Austrians hosted the first round of diplomatic negotiations, which yielded the Paris Convention for the Protection of Industrial Property in 1883 (WIPO 2004, Ch. 5). The Paris Convention did not call for harmonization of technical rules; rather, the member states agreed to certain basic principles, but retained control over IP standard setting. Following the principle of "national treatment," each member country had to grant to nationals and residents of the other member countries the same IP protection as it granted to its own nationals (ibid.).

The original signatories to the Convention were only 14 , mostly Western countries. ${ }^{1}$ However, membership increased significantly during the first quarter of the 20th century.

After World War II, more and more developing countries joined the Convention, and began to use their political leverage to ease patent restrictions. Furthermore, as enforcing mechanisms were virtually inexistent, a lot of free riding was tolerated (Braithwaite and Drahos 2000). ${ }^{2}$ In order to protect

1 The original 14 member countries of the Paris Convention for the Protection of Industrial Property were: Belgium, Brazil, Ecuador, El Salvador, France, Great Britain, Guatemala, Italy, the Netherlands, Portugal, Serbia, Spain, Switzerland, and Tunisia.

2 The only available enforcement mechanism was appealing to the International Court of Justice, and most states made reservations on such clauses (Braithwaite and Drahos 2000). 
its interests in patent-intensive sectors (e.g., pharmaceuticals, machinery), the US devised the strategy of linking intellectual property to trade, and put it in action by introducing clauses on minimum IP standards in its bilateral trade agreements.

The opportunity to give this trade-based strategy a global dimension came in 1986, with the launch of the Uruguay Round of multilateral trade negotiations. With the support of Europe, Canada, and Japan, the US introduced intellectual property in the agenda. TRIPS was negotiated at the end of the Round, and it came into effect in 1995. Its ratification was a compulsory requirement for countries that wanted to join the newborn World Trade Organization (WTO), and its enforcement was covered under the WTO dispute settlement system.

The implementation of TRIPS caused a massive wealth redistribution effect. According to McCalman (2001), the US was the major beneficiary, followed by France, Italy, Sweden and Switzerland. Developing countries were hit the hardest, but Canada, Japan, and the United Kingdom also experienced a net loss.

Developing countries were allowed a 10-year transitional period to comply with TRIPS, which expired in 2005. The transitional period was extended to 2013 for least developed countries, on condition that they provide information by 2008 on their "needs for technical and financial cooperation in order to assist them taking steps necessary to implement the TRIPS Agreement," 3 and ensure that any changes in their IP legislation made during the additional transitional period would not "result in a lesser degree of consistency with the provisions of the TRIPS Agreement". ${ }^{4}$

At the Doha Ministerial Conference in 2001, additional flexibilities were adopted for developing country members to protect public health. ${ }^{5}$ They include the right to grant compulsory licenses, limits on data protection, use of broad research, and other exceptions to patentability. However, many developing countries have not taken advantage of the flexibilities provided under TRIPS, due to both lack of legal and technical expertise, and pressure from developed countries-the US in particular-to implement tighter intellectual property standards (Musungu and Oh 2005, Braithwaite and Drahos 2000).

\footnotetext{
Decision of the Council for TRIPS of 29 November 2005 (IP/C/40), par. 2. Ibid., par. 5.

Declaration on the TRIPS Agreement and Public Health (WT/MIN(01)/DEC/2) adopted on November 14, 2001 , par. 4.
} 
Table A.1: Overview of the Dataset

\begin{tabular}{|c|c|c|c|c|c|c|c|c|c|c|}
\hline & 2002 & 2003 & 2004 & 2005 & 2006 & 2007 & 2008 & 2009 & 2010 & Total \\
\hline \multicolumn{11}{|l|}{ Angola } \\
\hline Number of observations & 0 & 0 & 0 & 0 & 208 & 0 & 0 & 0 & 126 & \multirow[t]{2}{*}{334} \\
\hline Proportion of licensees & - & - & - & - & 0.06 & - & - & - & 0.36 & \\
\hline \multicolumn{11}{|l|}{ Argentina } \\
\hline Number of observations & 0 & 0 & 0 & 0 & 623 & 0 & 0 & 0 & 764 & \multirow{2}{*}{1,387} \\
\hline Proportion of licensees & - & - & - & - & 0.16 & - & - & - & 0.17 & \\
\hline \multicolumn{11}{|l|}{ Bolivia } \\
\hline Number of observations & 0 & 0 & 0 & 0 & 343 & 0 & 0 & 0 & 104 & \multirow[t]{2}{*}{447} \\
\hline Proportion of licensees & - & - & - & - & 0.10 & - & - & - & 0.25 & \\
\hline \multicolumn{11}{|l|}{ Botswana } \\
\hline Number of observations & 0 & 0 & 0 & 0 & 113 & 0 & 0 & 0 & 87 & \multirow[t]{2}{*}{200} \\
\hline Proportion of licensees & - & - & - & - & 0.21 & - & - & - & 0.19 & \\
\hline \multicolumn{11}{|l|}{ Brazil } \\
\hline Number of observations & 0 & 1,490 & 0 & 0 & 0 & 0 & 0 & 862 & 0 & \multirow[t]{2}{*}{2,352} \\
\hline Proportion of licensees & - & 0.08 & - & - & - & - & - & 0.16 & - & \\
\hline \multicolumn{11}{|l|}{ Bulgaria } \\
\hline Number of observations & 0 & 0 & 0 & 227 & 0 & 372 & 0 & 47 & 0 & \multirow[t]{2}{*}{646} \\
\hline Proportion of licensees & - & - & - & 0.00 & - & 0.12 & - & 0.21 & - & \\
\hline \multicolumn{11}{|l|}{ Burkina Faso } \\
\hline Number of observations & 0 & 0 & 0 & 0 & 51 & 0 & 0 & 85 & 0 & \multirow[t]{2}{*}{136} \\
\hline Proportion of licensees & - & - & - & - & 0.08 & - & - & 0.08 & - & \\
\hline \multicolumn{11}{|l|}{ Cameroon } \\
\hline Number of observations & 0 & 0 & 0 & 0 & 117 & 0 & 0 & 110 & 0 & \multirow{2}{*}{227} \\
\hline Proportion of licensees & - & - & - & - & 0.13 & - & - & 0.16 & - & \\
\hline Chile & & & & & & & & & & \\
\hline Number of observations & 0 & 0 & 0 & 0 & 621 & 0 & 0 & 0 & 761 & 1,382 \\
\hline Proportion of licensees & - & - & - & - & 0.13 & - & - & - & 0.17 & \\
\hline Colombia & & & & & & & & & & \\
\hline Number of observations & 0 & 0 & 0 & 0 & 630 & 0 & 0 & 0 & 701 & 1,331 \\
\hline Proportion of licensees & - & - & - & - & 0.04 & - & - & - & 0.12 & \\
\hline Congo, Democratic Republic & & & & & & & & & & \\
\hline Number of observations & 0 & 0 & 0 & 0 & 149 & 0 & 0 & 0 & 112 & 261 \\
\hline Proportion of licensees & - & - & - & - & 0.03 & - & - & - & 0.07 & \\
\hline Costa Rica & & & & & & & & & & \\
\hline Number of observations & 0 & 0 & 0 & 331 & 0 & 0 & 0 & 0 & 309 & 640 \\
\hline Proportion of licensees & - & - & - & 0.33 & - & - & - & - & 0.08 & \\
\hline Dominican Republic & & & & & & & & & & \\
\hline Number of observations & 0 & 0 & 0 & 80 & 0 & 0 & 0 & 0 & 104 & 184 \\
\hline Proportion of licensees & - & - & - & 0.29 & - & - & - & - & 0.21 & \\
\hline Ecuador & & & & & & & & & & \\
\hline Number of observations & 0 & 399 & 0 & 0 & 514 & 0 & 0 & 0 & 117 & 1,030 \\
\hline Proportion of licensees & - & 0.24 & - & - & 0.14 & - & - & - & 0.14 & \\
\hline Egypt & & & & & & & & & & \\
\hline Number of observations & 0 & 0 & 954 & 0 & 0 & 992 & 0 & 0 & 0 & 1,946 \\
\hline Proportion of licensees & - & - & 0.09 & - & - & 0.09 & - & - & - & \\
\hline El Salvador & & & & & & & & & & \\
\hline Number of observations & 0 & 446 & 0 & 0 & 431 & 0 & 0 & 0 & 0 & 877 \\
\hline Proportion of licensees & - & 0.13 & - & - & 0.18 & - & - & - & - & \\
\hline Guatemala & & & & & & & & & & \\
\hline Number of observations & 0 & 448 & 0 & 0 & 308 & 0 & 0 & 0 & 349 & 1,105 \\
\hline Proportion of licensees & - & 0.20 & - & - & 0.25 & - & - & - & 0.16 & \\
\hline Honduras & & & & & & & & & & \\
\hline Number of observations & 0 & 431 & 0 & 0 & 256 & 0 & 0 & 0 & 0 & 687 \\
\hline Proportion of licensees & - & 0.15 & - & - & 0.11 & - & - & - & - & \\
\hline
\end{tabular}




\begin{tabular}{|c|c|c|c|c|c|c|c|c|c|c|}
\hline & 2002 & 2003 & 2004 & 2005 & 2006 & 2007 & 2008 & 2009 & 2010 & Total \\
\hline \multicolumn{11}{|l|}{ Jamaica } \\
\hline Number of observations & 0 & 0 & 0 & 62 & 0 & 0 & 0 & 0 & 107 & \multirow[t]{2}{*}{169} \\
\hline Proportion of licensees & - & - & - & 0.18 & - & - & - & - & 0.14 & \\
\hline \multicolumn{11}{|l|}{ Kenya } \\
\hline Number of observations & 0 & 0 & 0 & 0 & 0 & 396 & 0 & 0 & 0 & \multirow[t]{2}{*}{396} \\
\hline Proportion of licensees & - & 0.00 & - & - & - & 0.15 & - & - & - & \\
\hline \multicolumn{11}{|l|}{ Lithuania } \\
\hline Number of observations & 0 & 0 & 0 & 138 & 0 & 0 & 0 & 61 & 0 & \multirow[t]{2}{*}{199} \\
\hline Proportion of licensees & - & - & - & 0.00 & - & - & - & 0.36 & - & \\
\hline \multicolumn{11}{|l|}{ Madagascar } \\
\hline Number of observations & 0 & 0 & 0 & 271 & 0 & 0 & 0 & 202 & 0 & \multirow[t]{2}{*}{473} \\
\hline Proportion of licensees & - & - & - & 0.07 & - & - & - & 0.11 & - & \\
\hline \multicolumn{11}{|l|}{ Malawi } \\
\hline Number of observations & 0 & 0 & 0 & 146 & 0 & 0 & 0 & 75 & 0 & \multirow[t]{2}{*}{221} \\
\hline Proportion of licensees & - & - & - & 0.15 & - & - & - & 0.21 & - & \\
\hline \multicolumn{11}{|l|}{ Mali } \\
\hline Number of observations & 0 & 119 & 0 & 0 & 0 & 301 & 0 & 0 & 80 & \multirow[t]{2}{*}{500} \\
\hline Proportion of licensees & - & 0.08 & - & - & - & 0.07 & - & - & 0.09 & \\
\hline \multicolumn{11}{|l|}{ Mauritius } \\
\hline Number of observations & 0 & 0 & 0 & 157 & 0 & 0 & 0 & 127 & 0 & \multirow[t]{2}{*}{284} \\
\hline Proportion of licensees & - & - & - & 0.18 & - & - & - & 0.17 & - & \\
\hline \multicolumn{11}{|l|}{ Mexico } \\
\hline Number of observations & 0 & 0 & 0 & 0 & 1,049 & 0 & 0 & 0 & 1,131 & \multirow[t]{2}{*}{2,180} \\
\hline Proportion of licensees & - & - & - & - & 0.10 & - & - & - & 0.15 & \\
\hline Morocco & & & & & & & & & & \\
\hline Number of observations & 0 & 0 & 820 & 0 & 0 & 451 & 0 & 0 & 0 & 1,271 \\
\hline Proportion of licensees & - & - & 0.06 & - & - & 0.13 & - & - & - & \\
\hline Nicaragua & & & & & & & & & & \\
\hline Number of observations & 0 & 447 & 0 & 0 & 345 & 0 & 0 & 0 & 0 & 792 \\
\hline Proportion of licensees & - & 0.09 & - & - & 0.07 & - & - & - & - & \\
\hline Niger & & & & & & & & & & \\
\hline Number of observations & 0 & 0 & 0 & 6 & 0 & 0 & 0 & 32 & 0 & 38 \\
\hline Proportion of licensees & - & - & - & 0.00 & - & - & - & 0.11 & - & \\
\hline Nigeria & & & & & & & & & & \\
\hline Number of observations & 0 & 0 & 0 & 0 & 0 & 947 & 0 & 0 & 1,549 & 2,496 \\
\hline Proportion of licensees & - & - & - & - & - & 0.10 & - & - & 0.19 & \\
\hline Panama & & & & & & & & & & \\
\hline Number of observations & 0 & 0 & 0 & 0 & 228 & 0 & 0 & 0 & 104 & 332 \\
\hline Proportion of licensees & - & - & - & - & 0.11 & - & - & - & 0.29 & \\
\hline Paraguay & & & & & & & & & & \\
\hline Number of observations & 0 & 0 & 0 & 0 & 362 & 0 & 0 & 0 & 116 & 478 \\
\hline Proportion of licensees & - & - & - & - & 0.11 & - & - & - & 0.12 & \\
\hline Peru & & & & & & & & & & \\
\hline Number of observations & 0 & 0 & 0 & 0 & 355 & 0 & 0 & 0 & 756 & 1,111 \\
\hline Proportion of licensees & - & - & - & - & 0.11 & - & - & - & 0.13 & \\
\hline Romania & & & & & & & & & & \\
\hline Number of observations & 0 & 0 & 0 & 479 & 0 & 0 & 0 & 82 & 0 & 561 \\
\hline Proportion of licensees & - & - & - & 0.01 & - & - & - & 0.25 & - & \\
\hline Russian Federation & & & & & & & & & & \\
\hline Number of observations & 0 & 0 & 0 & 405 & 0 & 0 & 0 & 364 & 0 & 769 \\
\hline Proportion of licensees & - & - & - & 0.00 & - & - & - & 0.28 & - & \\
\hline Senegal & & & & & & & & & & \\
\hline Number of observations & 0 & 196 & 0 & 0 & 0 & 258 & 0 & 0 & 0 & 454 \\
\hline Proportion of licensees & - & 0.16 & - & - & - & 0.08 & - & - & - & \\
\hline
\end{tabular}


Table A.1 continued

\begin{tabular}{|c|c|c|c|c|c|c|c|c|c|c|}
\hline & & 2002 & 2003 & 2004 & 2005 & 2006 & 2007 & 2008 & 2009 & 2010 \\
\hline \multicolumn{11}{|l|}{ South Africa } \\
\hline Number of observations & 0 & 584 & 0 & 0 & 0 & 677 & 0 & 0 & 0 & \multirow[t]{2}{*}{1,261} \\
\hline Proportion of licensees & - & 0.22 & - & - & - & 0.13 & - & - & - & \\
\hline \multicolumn{11}{|l|}{ Tanzania } \\
\hline Number of observations & 0 & 221 & 0 & 0 & 268 & 0 & 0 & 0 & 0 & \multirow[t]{2}{*}{489} \\
\hline Proportion of licensees & - & 0.15 & - & - & 0.14 & - & - & - & - & \\
\hline \multicolumn{11}{|l|}{ Turkey } \\
\hline Number of observations & 0 & 0 & 0 & 949 & 0 & 0 & 783 & 0 & 0 & \multirow[t]{2}{*}{1,732} \\
\hline Proportion of licensees & - & - & - & 0.14 & - & - & 0.24 & - & - & \\
\hline \multicolumn{11}{|l|}{ Ukraine } \\
\hline Number of observations & 0 & 0 & 0 & 390 & 0 & 0 & 417 & 0 & 0 & \multirow[t]{2}{*}{807} \\
\hline Proportion of licensees & - & - & - & 0.00 & - & - & 0.20 & - & - & \\
\hline \multicolumn{11}{|l|}{ Uruguay } \\
\hline Number of observations & 0 & 0 & 0 & 0 & 337 & 0 & 0 & 0 & 351 & \multirow[t]{2}{*}{688} \\
\hline Proportion of licensees & - & - & - & - & 0.05 & - & - & - & 0.10 & \\
\hline \multicolumn{11}{|l|}{ Zambia } \\
\hline Number of observations & 195 & 0 & 0 & 0 & 0 & 304 & 0 & 0 & 0 & \multirow[t]{2}{*}{499} \\
\hline Proportion of licensees & 0.07 & - & - & - & - & 0.24 & - & - & - & \\
\hline Total & 195 & 4,781 & 1,774 & 3,641 & 7,308 & 4,698 & 1,200 & 2,047 & 7,728 & 33,372 \\
\hline
\end{tabular}

Source: Author's calculations. 
30 | Appendix

Table A.2: Index of Patent Rights by Country by Year ${ }^{\mathrm{a}}$

\begin{tabular}{|c|c|c|c|c|c|c|c|c|c|}
\hline & 2002 & 2003 & 2004 & 2005 & 2006 & 2007 & 2008 & 2009 & 2010 \\
\hline Angola & 1.075 & 1.075 & 1.075 & 1.075 & 1.200 & 1.200 & 1.200 & 1.200 & 1.200 \\
\hline Argentina & 3.975 & 3.975 & 3.975 & 3.975 & 3.975 & 3.975 & 3.975 & 3.975 & 3.975 \\
\hline Bolivia & 3.433 & 3.433 & 3.433 & 3.433 & 3.433 & 3.433 & 3.433 & 3.433 & 3.433 \\
\hline Botswana & 3.317 & 3.317 & 3.317 & 3.317 & 3.517 & 3.517 & 3.517 & 3.517 & 3.517 \\
\hline Brazil & 3.592 & 3.592 & 3.592 & 3.592 & 3.592 & 3.592 & 3.592 & 3.592 & 3.592 \\
\hline Bulgaria & 4.417 & 4.417 & 4.417 & 4.417 & 4.542 & 4.542 & 4.542 & 4.542 & 4.542 \\
\hline Burkina Faso & 2.100 & 2.100 & 2.100 & 2.100 & 2.933 & 2.933 & 2.933 & 2.933 & 2.933 \\
\hline Cameroon & 2.225 & 2.225 & 2.225 & 2.225 & 3.058 & 3.058 & 3.058 & 3.058 & 3.058 \\
\hline Chile & 4.275 & 4.275 & 4.275 & 4.275 & 4.275 & 4.275 & 4.275 & 4.275 & 4.275 \\
\hline Colombia & 3.592 & 3.592 & 3.592 & 3.592 & 3.717 & 3.717 & 3.717 & 3.717 & 3.717 \\
\hline Congo, Democratic Republic & 1.775 & 1.775 & 1.775 & 1.775 & 2.233 & 2.233 & 2.233 & 2.233 & 2.233 \\
\hline Costa Rica & 2.892 & 2.892 & 2.892 & 2.892 & 2.892 & 2.892 & 2.892 & 2.892 & 2.892 \\
\hline Dominican Republic & 2.447 & 2.447 & 2.447 & 2.447 & 2.817 & 2.817 & 2.817 & 2.817 & 2.817 \\
\hline Ecuador & 3.725 & 3.725 & 3.725 & 3.725 & 3.725 & 3.725 & 3.725 & 3.725 & 3.725 \\
\hline Egypt & 1.858 & 1.858 & 1.858 & 1.858 & 2.767 & 2.767 & 2.767 & 2.767 & 2.767 \\
\hline El Salvador & 3.358 & 3.358 & 3.358 & 3.358 & 3.483 & 3.483 & 3.483 & 3.483 & 3.483 \\
\hline Guatemala & 1.275 & 1.275 & 1.275 & 1.275 & 3.150 & 3.150 & 3.150 & 3.150 & 3.150 \\
\hline Honduras & 2.858 & 2.858 & 2.858 & 2.858 & 2.983 & 2.983 & 2.983 & 2.983 & 2.983 \\
\hline Jamaica & 3.058 & 3.058 & 3.058 & 3.058 & 3.358 & 3.358 & 3.358 & 3.358 & 3.358 \\
\hline Kenya & 2.883 & 2.883 & 2.883 & 2.883 & 3.217 & 3.217 & 3.217 & 3.217 & 3.217 \\
\hline Lithuania & 3.475 & 3.475 & 3.475 & 3.475 & 4.000 & 4.000 & 4.000 & 4.000 & 4.000 \\
\hline Madagascar & 2.308 & 2.308 & 2.308 & 2.308 & 2.308 & 2.308 & 2.308 & 2.308 & 2.308 \\
\hline Malawi & 2.150 & 2.150 & 2.150 & 2.150 & 2.150 & 2.150 & 2.150 & 2.150 & 2.150 \\
\hline Mali & 2.100 & 2.100 & 2.100 & 2.100 & 2.933 & 2.933 & 2.933 & 2.933 & 2.933 \\
\hline Mauritius & 1.933 & 1.933 & 1.933 & 1.933 & 2.567 & 2.567 & 2.567 & 2.567 & 2.567 \\
\hline Mexico & 3.675 & 3.675 & 3.675 & 3.675 & 3.875 & 3.875 & 3.875 & 3.875 & 3.875 \\
\hline Morocco & 3.058 & 3.058 & 3.058 & 3.058 & 3.517 & 3.517 & 3.517 & 3.517 & 3.517 \\
\hline Nicaragua & 2.157 & 2.157 & 2.157 & 2.157 & 2.967 & 2.967 & 2.967 & 2.967 & 2.967 \\
\hline Niger & 2.100 & 2.100 & 2.100 & 2.100 & 2.933 & 2.933 & 2.933 & 2.933 & 2.933 \\
\hline Nigeria & 2.858 & 2.858 & 2.858 & 2.858 & 3.183 & 3.183 & 3.183 & 3.183 & 3.183 \\
\hline Panama & 3.642 & 3.642 & 3.642 & 3.642 & 3.642 & 3.642 & 3.642 & 3.642 & 3.642 \\
\hline Paraguay & 2.392 & 2.392 & 2.392 & 2.392 & 2.892 & 2.892 & 2.892 & 2.892 & 2.892 \\
\hline Peru & 3.317 & 3.317 & 3.317 & 3.317 & 3.317 & 3.317 & 3.317 & 3.317 & 3.317 \\
\hline Romania & 3.717 & 3.717 & 3.717 & 3.717 & 4.167 & 4.167 & 4.167 & 4.167 & 4.167 \\
\hline Russian Federation & 3.675 & 3.675 & 3.675 & 3.675 & 3.675 & 3.675 & 3.675 & 3.675 & 3.675 \\
\hline Senegal & 2.100 & 2.100 & 2.100 & 2.100 & 2.933 & 2.933 & 2.933 & 2.933 & 2.933 \\
\hline South Africa & 4.250 & 4.250 & 4.250 & 4.250 & 4.250 & 4.250 & 4.250 & 4.250 & 4.250 \\
\hline Tanzania & 2.642 & 2.642 & 2.642 & 2.642 & 2.642 & 2.642 & 2.642 & 2.642 & 2.642 \\
\hline Turkey & 4.008 & 4.008 & 4.008 & 4.008 & 4.008 & 4.008 & 4.008 & 4.008 & 4.008 \\
\hline Ukraine & 3.675 & 3.675 & 3.675 & 3.675 & 3.675 & 3.675 & 3.675 & 3.675 & 3.675 \\
\hline Uruguay & 3.272 & 3.272 & 3.272 & 3.272 & 3.392 & 3.392 & 3.392 & 3.392 & 3.392 \\
\hline Zambia & 1.742 & 1.742 & 1.742 & 1.742 & 1.942 & 1.942 & 1.942 & 1.942 & 1.942 \\
\hline
\end{tabular}

a The Index of Patent Rights in ranges between 0 (lowest protection) and 5 (highest protection), and is updated at 5-year intervals. Source: Park (2008). 


\section{Table A.3: Overview of the Subpopulation of Small and Medium Enterprises with Domestic Ownership and Domestic Sales}

\begin{tabular}{|c|c|c|c|c|c|c|c|c|c|c|}
\hline & 2002 & 2003 & 2004 & 2005 & 2006 & 2007 & 2008 & 2009 & 2010 & Total \\
\hline \multicolumn{11}{|l|}{ Angola } \\
\hline Number of observations & 0 & 0 & 0 & 0 & 184 & 0 & 0 & 0 & 78 & 262 \\
\hline Proportion of licensees & - & - & - & - & 0.03 & - & - & - & 0.31 & \\
\hline \multicolumn{11}{|l|}{ Argentina } \\
\hline Number of observations & 0 & 0 & 0 & 0 & 275 & 0 & 0 & 0 & 297 & 572 \\
\hline Proportion of licensees & - & - & - & - & 0.13 & - & - & - & 0.04 & \\
\hline \multicolumn{11}{|l|}{ Bolivia } \\
\hline Number of observations & 0 & 0 & 0 & 0 & 215 & 0 & 0 & 0 & 47 & 262 \\
\hline Proportion of licensees & - & - & - & - & 0.06 & - & - & - & 0.26 & \\
\hline \multicolumn{11}{|l|}{ Botswana } \\
\hline Number of observations & 0 & 0 & 0 & 0 & 45 & 0 & 0 & 0 & 35 & 80 \\
\hline Proportion of licensees & - & - & - & - & 0.22 & - & - & - & 0.17 & \\
\hline \multicolumn{11}{|l|}{ Brazil } \\
\hline Number of observations & 0 & 861 & 0 & 0 & 0 & 0 & 0 & 561 & 0 & 1,422 \\
\hline Proportion of licensees & - & 0.03 & - & - & - & - & - & 0.08 & - & \\
\hline \multicolumn{11}{|l|}{ Bulgaria } \\
\hline Number of observations & 0 & 0 & 0 & 142 & 0 & 148 & 0 & 21 & 0 & 311 \\
\hline Proportion of licensees & - & - & - & 0.00 & - & 0.09 & - & 0.16 & - & \\
\hline \multicolumn{11}{|l|}{ Burkina Faso } \\
\hline Number of observations & 0 & 0 & 0 & 0 & 28 & 0 & 0 & 44 & 0 & 72 \\
\hline Proportion of licensees & - & - & - & - & 0.00 & - & - & 0.02 & - & \\
\hline \multicolumn{11}{|l|}{ Cameroon } \\
\hline Number of observations & 0 & 0 & 0 & 0 & 51 & 0 & 0 & 62 & 0 & 113 \\
\hline Proportion of licensees & - & - & - & - & 0.12 & - & - & 0.05 & - & \\
\hline \multicolumn{11}{|l|}{ Chile } \\
\hline Number of observations & 0 & 0 & 0 & 0 & 374 & 0 & 0 & 0 & 408 & 782 \\
\hline \multicolumn{10}{|l|}{ Colombia } & \\
\hline Number of observations & 0 & 0 & 0 & 0 & 425 & 0 & 0 & 0 & 343 & 768 \\
\hline Proportion of licensees & - & - & - & - & 0.03 & - & - & - & 0.04 & \\
\hline \multicolumn{11}{|l|}{ Congo, Democratic Republic } \\
\hline Number of observations & 0 & 0 & 0 & 0 & 95 & 0 & 0 & 0 & 83 & 178 \\
\hline Proportion of licensees & - & - & - & - & 0.00 & - & - & - & 0.05 & \\
\hline \multicolumn{11}{|l|}{ Costa Rica } \\
\hline Number of observations & 0 & 0 & 0 & 214 & 0 & 0 & 0 & 0 & 168 & 382 \\
\hline Proportion of licensees & - & - & - & 0.21 & - & - & - & - & 0.03 & \\
\hline \multicolumn{11}{|l|}{ Dominican Republic } \\
\hline Number of observations & 0 & 0 & 0 & 54 & 0 & 0 & 0 & 0 & 46 & 100 \\
\hline Proportion of licensees & - & - & - & 0.20 & - & - & - & - & 0.16 & \\
\hline \multicolumn{11}{|l|}{ Ecuador } \\
\hline Number of observations & 0 & 251 & 0 & 0 & 290 & 0 & 0 & 0 & 59 & 600 \\
\hline Proportion of licensees & - & 0.19 & - & - & 0.11 & - & - & - & 0.13 & \\
\hline \multicolumn{11}{|l|}{ Egypt } \\
\hline Number of observations & 0 & 0 & 645 & 0 & 0 & 467 & 0 & 0 & 0 & 1,112 \\
\hline \multirow{2}{*}{\multicolumn{11}{|c|}{ El Salvador }} \\
\hline & & & & & & & & & & \\
\hline Number of observations & 0 & 229 & 0 & 0 & 219 & 0 & 0 & 0 & 0 & 448 \\
\hline Proportion of licensees & - & 0.07 & - & - & 0.09 & - & - & - & - & \\
\hline \multicolumn{11}{|l|}{ Guatemala } \\
\hline Number of observations & 0 & 257 & 0 & 0 & 162 & 0 & 0 & 0 & 158 & 577 \\
\hline Proportion of licensees & - & 0.11 & - & - & 0.25 & - & - & - & 0.06 & \\
\hline
\end{tabular}




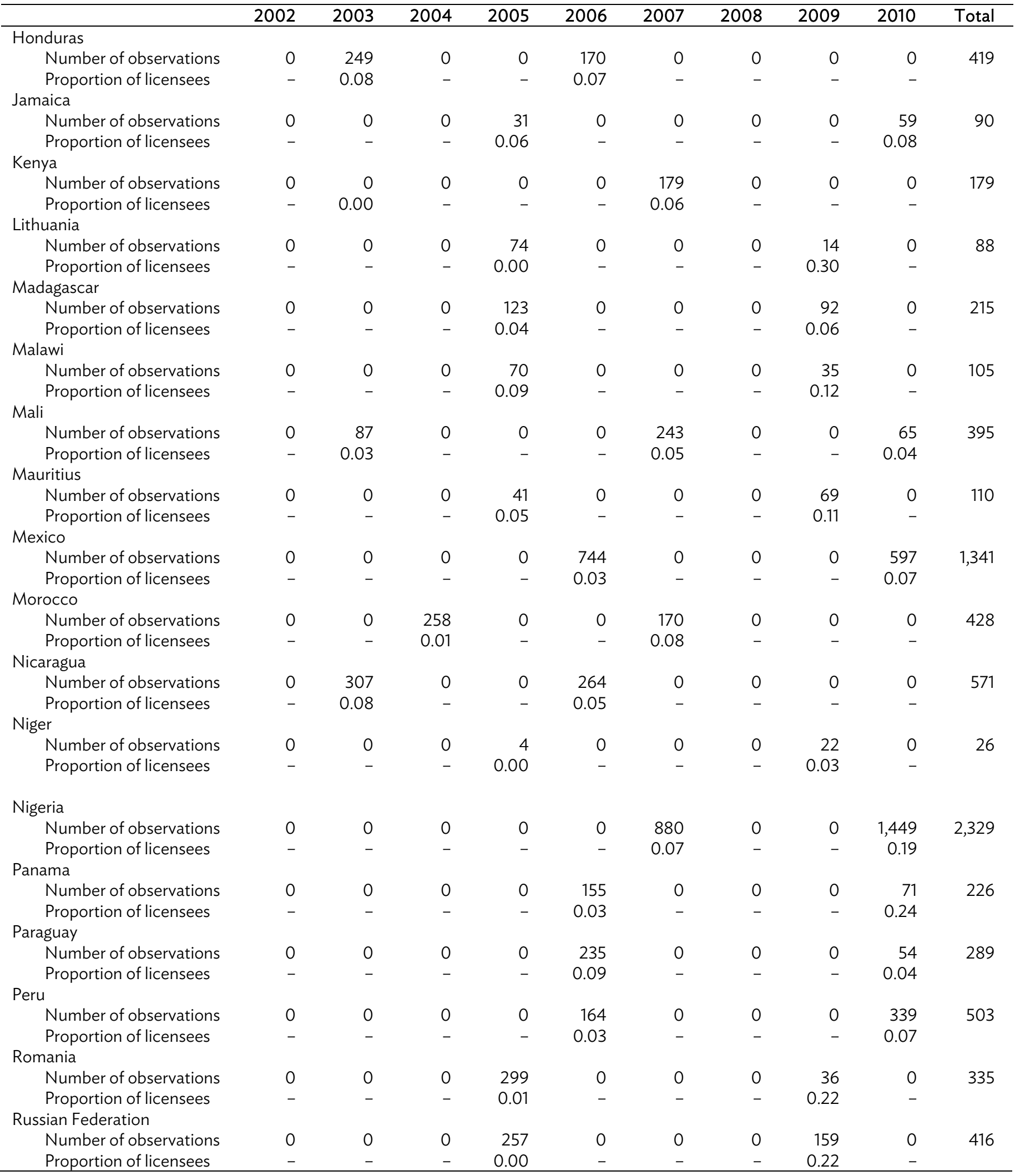


Table A.3 continued

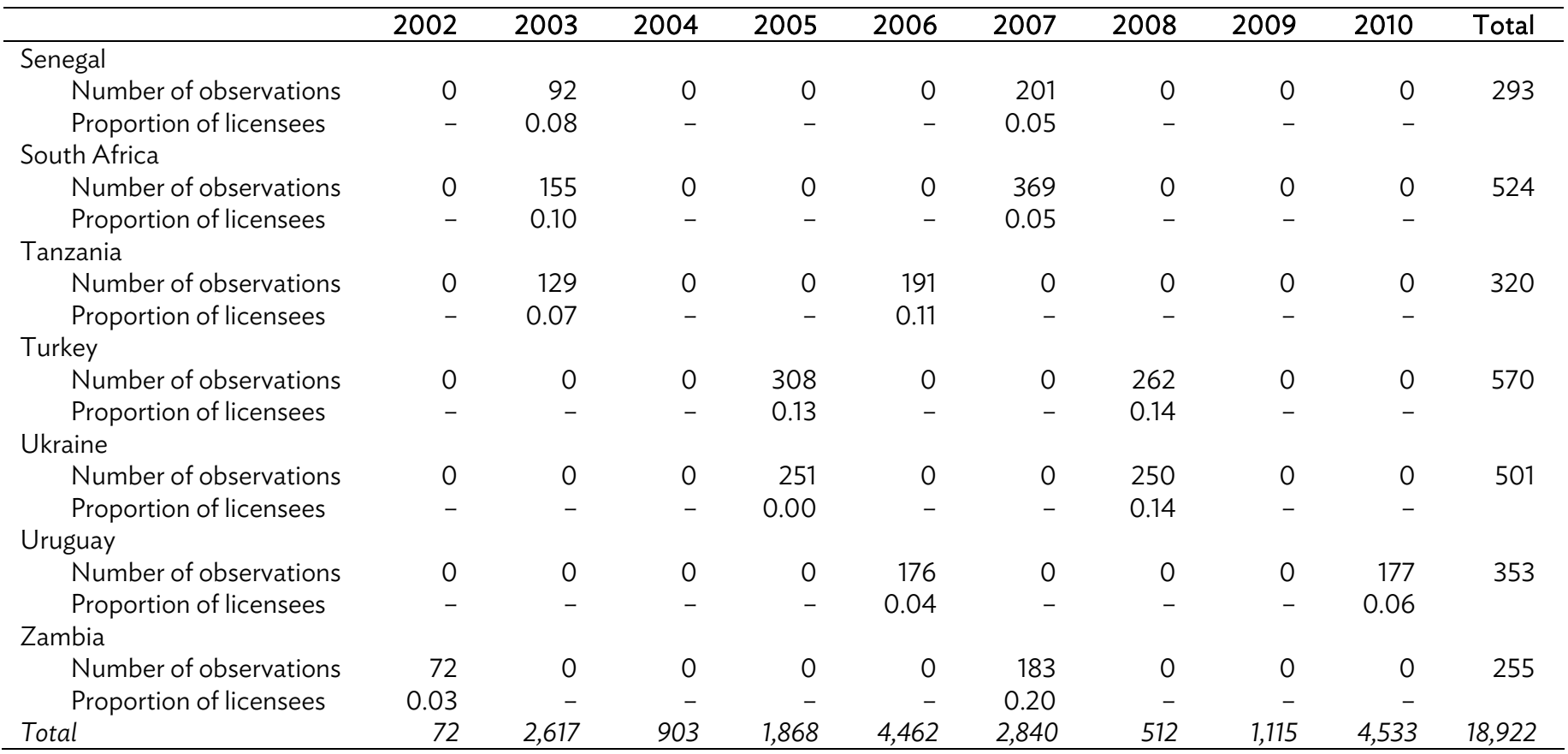

Source: Author's calculations. 


\section{REFERENCES}

Aterido, Reyes, and Mary Hallward-Driemeier. 2010. "The Impact of the Investment Climate on Employment Growth: Does Sub-Saharan Africa Mirror Other Low-Income Regions?” World Bank Policy Research Working Paper No. 5218.

Barro, Robert J., and Jong-Wha Lee. 2010. "A New Data Set of Educational Attainment in the World, 1950-2010.” NBER Working Paper No 15902.

Boldrin, Michele, and David Levine. 2002. "The Case Against Intellectual Property." The American Economic Review 92 (2): 209-12.

Braithwaite, John, and Peter Drahos. 2000. Global Business Regulation. Cambridge University Press.

Branstetter, Lee G., Raymond Fisman, and C. Fritz Foley. 2006. “Do Stronger Intellectual Property Rights Increase International Technology Transfer? Empirical Evidence from U. S. Firm-Level Panel Data." Quarterly Journal of Economics 121 (1): 321-49.

Branstetter, Lee G., Raymond Fisman, C. Fritz Foley, and Kamal Saggi. 2011. "Does Intellectual Property Rights Reform Spur Industrial Development?” Journal of International Economics 83 (1): 27-36.

Caselli, Francesco. 2005. "Accounting for Cross-Country Income Differences." In Handbook of Economic Growth, Volume 1, edited by Philippe Aghion and Steven Durlauf, 679-741.

Chaudhuri, Shubham, Penelopi K. Goldberg, and Panle Jia. 2006. "Estimating the Effects of Global Patent Protection in Pharmaceuticals: A Case Study of Quinolones in India." The American Economic Review 96 (5): 1477-514.

Deere, Carolyn. 2010. The Implementation Game: The TRIPS Agreement and the Global Politics of Intellectual Property Reform in Developing Countries. Oxford University Press.

Dethier, Jean-Jacques, Maximilian Hirn, and Stephane Straub. 2011. "Explaining Enterprise Performance in Developing Countries with Business Climate Survey Data." The World Bank Research Observer 26 (2): 258-309.

Dinopoulos, Elias, and Paul Segerstrom. 2010. "Intellectual Property Rights, Multinational Firms and Economic Growth.” Journal of Development Economics 92 (1): 13-27.

Galasso, Alberto, and Mark Schankerman. 2015. "Patents and Cumulative Innovation: Causal Evidence from the Courts." The Quarterly Journal of Economics 130 (1): 317-69.

General Agreement on Tariffs and Trade (GATT). 1994. Agreement on Trade-Related Aspects of Intellectual Property Rights, April 15, 1994, Marrakesh Agreement Establishing the World Trade Organization, Annex 1C.

Glass, Amy J., and Kamal Saggi. 2002. "Intellectual Property Rights and Foreign Direct Investment." Journal of International Economics 56 (2): 387-410. 
Gwartney, James, Robert Lawson, and Joshua Hall. 2012. Economic Freedom of the World: 2012 Annual Report. Economic Freedom Network.

Helpman, Elhanan. 1993. “Innovation, Imitation, and Intellectual Property Rights.” Econometrica 61 (6): 1247-80.

Hu, Albert G. Z., and Ivan P. L. Png. 2013. "Patent Rights and Economic Growth: Evidence from CrossCountry Panels of Manufacturing Industries." Oxford Economic Papers 65 (3): 675-98.

Johns, Adrian. 2009. Piracy: The Intellectual Property Wars from Gutenberg to Gates. University of Chicago Press.

Kanwar, Sunil. 2012. "The Location of Overseas Research and Development and Intellectual Property Protection." The Journal of Development Studies 48 (10): 1453-69.

Kanwar, Sunil, and Robert Evenson. 2003. "Does Intellectual Property Protection Spur Technological Change?” Oxford Economic Papers 55 (2): 235-64.

Kim, Yee Kyoung, Keun Lee, Walter G. Park, and Kineung Choo. 2012. "Appropriate Intellectual Property Protection and Economic Growth in Countries at Different Levels of Development." Research Policy 41 (2): 358-75.

Lai, Edwin L.-C. 1998. "International Intellectual Property Rights Protection and the Rate of Product Innovation.” Journal of Development Economics 55 (1): 133-53.

Maskus, Keith E., and Mohan Penubarti. 1995. "How Trade-Related are Intellectual Property Rights?" Journal of International Economics 39 (3-4): 227-48.

McCalman, Phillip. 2001. "Reaping What You Sow: An Empirical Analysis of International Patent Harmonization." Journal of International Economics 55 (1): 161-86.

Moser, Petra. 2005. "How Do Patent Laws Influence Innovation? Evidence from Nineteenth-Century World's Fairs." The American Economic Review 95 (4): 1214-36.

Moser, Petra, and Alessandra Voena. 2012. "Compulsory Licensing: Evidence from the Trading with the Enemy Act." The American Economic Review 102 (1): 396-427.

Mossoff, Adam. 2001. "Rethinking the Development of Patents: An Intellectual History, 1550-1800." Hastings Law Journal 52: 1255-322.

Musungu, Sisule F., and Cecilia Oh. 2005, August. "The Use of Flexibilities in TRIPS by Developing Countries: Can They Promote Access to Medicines?" Technical Report 4C, World Health Organization.

Park, Walter G. 2008. “International Patent Protection: 1960-2005.” Research Policy 37 (4): 761-66.

Reichman, Jerome H., and Rochelle Cooper Dreyfuss. 2007. "Harmonization Without Consensus: Critical Reflections on Drafting a Substantive Patent Law Treaty.” Duke Law Journal 57 (1): 85130. 
Sampat, Bhaven, and Heidi L. Williams. 2015. "How Do Patents Affect Follow-On Innovation? Evidence from the Human Genome.” NBER Working Paper No. 21666.

Schaafsma, Paul E. 1997. “An Economic Overview of Patents.” Journal of the Patent and Trademark Office Society 79: 241.

Schwab, Klaus. 2010. The Global Competitiveness Report 2010-2011. Geneva: World Economic Forum.

United States Department of Commerce, ed. 2013. Survey of Current Business.

Wakasugi, Ryuhei, and Banri Ito. 2007. "Protection of Intellectual Property Rights and International Technology Transfer: Empirical Evidence." Unpublished paper presented at the 2007 APEA Conference, Hong Kong, China.

Williams, Heidi L. 2013. "Intellectual Property Rights and Innovation: Evidence from the Human Genome." Journal of Political Economy 121 (1): 1-27.

World Bank. 2016. Why Use GNI per Capita to Classify Economies into Income Groupings? https://datahelpdesk.worldbank.org/knowledgebase/articles/378831-why-use-gni-per-capitato-classify-economies-into. (accessed 17 March 2016).

World Intellectual Property Organization (WIPO), ed. 2004. WIPO Intellectual Property Handbook: Policy, Law and Use.

Yang, Guifang, and Keith E. Maskus. 2001a. "Intellectual Property Rights and Licensing: An Econometric Investigation.” Weltwirtschafliches Archiv 137 (1): 58-79.

- 2001b. "Intellectual Property Rights, Licensing and Innovation in an Endogenous ProductCycle Model." Journal of International Economics 53 (1): 169-87.

Yu, Peter K. 2007. “The International Enclosure Movement.” Indiana Law Journal 82 (4): 827-907.

Zuniga, Pluvia M., and Dominique Guellec. 2009. "Who Licenses out Patents and Why? Lessons from a Business Survey." OECD Science, Technology and Industry Working Papers 2009/05. 


\section{Intellectual Property Rights and Foreign Technology Licensing in Developing Countries: An Empirical Investigation}

Using cross-sectional analysis of a representative sample of firms operating in 42 developing economies, we investigate whether expanded and strengthened protection of intellectual property (IP) fosters technology transfer to developing countries. We find that going from no IP protection to maximum IP protection is associated with a $65 \%$ increase in the predicted probability of licensing foreign technology for affiliated firms, but not for unaffiliated firms. We also find evidence that the positive impact is limited to upper-middle-income countries, whereas there is at best no significant correlation for firms operating in lower-middle-income and low-income countries.

\section{About the Asian Development Bank}

ADB's vision is an Asia and Pacific region free of poverty. Its mission is to help its developing member countries reduce poverty and improve the quality of life of their people. Despite the region's many successes, it remains home to a large share of the world's poor. ADB is committed to reducing poverty through inclusive economic growth, environmentally sustainable growth, and regional integration.

Based in Manila, ADB is owned by 67 members, including 48 from the region. Its main instruments for helping its developing member countries are policy dialogue, loans, equity investments, guarantees, grants, and technical assistance. 